\title{
Discovery of S-217622, a Non-Covalent Oral SARS-CoV-2 3CL Protease Inhibitor Clinical Candidate for Treating COVID-19
}

Yuto Unoh $^{1 \dagger}$, Shota Uehara ${ }^{1 \dagger}$, Kenji Nakahara ${ }^{1 \dagger}$, Haruaki Nobori ${ }^{1}$, Yukiko Yamatsu ${ }^{1}$, Shiho Yamamoto $^{1}$, Yuki Maruyama ${ }^{1,2}$, Yoshiyuki Taoda ${ }^{1}$, Koji Kasamatsu $^{1}$, Takahiro Suto ${ }^{1}$, Kensuke Kouki ${ }^{1}$, Atsufumi Nakahashi ${ }^{1}$, Sho Kawashima ${ }^{1}$, Takao Sanaki ${ }^{1}$, Shinsuke Toba $^{1,2}$, Kentaro Uemura ${ }^{1,2}$, Tohru Mizutare ${ }^{1}$, Shigeru Ando ${ }^{1}$, Michihito Sasaki $^{2}$, Yasuko Orba $^{2}$, Hirofumi Sawa ${ }^{2}$, Akihiko Sato $^{1,2}$, Takafumi Sato ${ }^{1}$, Teruhisa Kato ${ }^{1}$, Yuki Tachibana $^{1 *}$

${ }^{1}$ Shionogi Pharmaceutical Research Center, 3-1-1 Futaba-cho, Toyonaka, Osaka, Japan

${ }^{2}$ International Institute for Zoonosis Control, Hokkaido University, Sapporo, Japan

*Corresponding author. Email: yuuki.tachibana@shionogi.co.jp

$\dagger$ These authors contributed equally to this work. 


\begin{abstract}
The coronavirus disease 2019 (COVID-19) pandemic, caused by severe acute respiratory syndrome coronavirus 2 (SARS-CoV-2), has resulted in millions of deaths and threatens public health and safety. Despite the rapid global spread of COVID-19 vaccines, effective oral antiviral drugs are urgently needed. Here, we describe the discovery of S-217622, the first oral non-covalent, non-peptidic SARS-CoV-2 3CL protease inhibitor clinical candidate. S-217622 was discovered via virtual screening followed by biological screening of an inhouse compound library, and optimization of the hit compound using a structure-based drugdesign strategy. S-217622 exhibited antiviral activity in vitro against current outbreaking SARS-CoV-2 variants and showed favorable pharmacokinetic profiles in vivo for once-daily oral dosing. Furthermore, S-217622 dose-dependently inhibited intrapulmonary replication of SARS-CoV-2 in mice, indicating that this novel non-covalent inhibitor could be a potential oral agent for treating COVID-19.
\end{abstract}

\title{
Introduction
}

The global coronavirus disease 2019 (COVID-19) pandemic, caused by severe acute respiratory syndrome coronavirus 2 (SARS-CoV-2), continues to spread worldwide; more than 315 million people have been infected, and 5.5 million have died as of January $2022 .{ }^{1}$ Because therapeutic options remain limited, oral COVID-19 therapeutics are urgently needed, especially for non-hospitalized patients, to prevent hospitalization and death. ${ }^{2}$ 
SARS-CoV-2 is highly pathogenic to older adults and persons with high risk factors and can develop into severe, life-threatening acute respiratory distress syndrome. SARS-CoV-2 is an enveloped positive-sense single-stranded RNA virus that is a member of the genus Betacoronavirus. ${ }^{3}$ SARS-CoV-2 enters host cells by binding its spike glycoprotein to angiotensin-converting enzyme 2 (ACE2) and releases its viral RNA genome into the cytoplasm after uncoating. After entry, the viral RNA genome subjects the cell to translation of two large polyproteins, ppla and pplab, which are processed into individual non-structural proteins. Nsp5, also known as $3 \mathrm{C}$-like protease $\left(3 \mathrm{CL}^{\text {pro }}\right)$ or the main protease, is a cysteine protease responsible for cleaving 11 distinct sites of the polyproteins to transform into mature functional proteins. $3 \mathrm{CL}^{\text {pro }}$ plays a critical role in viral replication, and its inhibition prevents formation of replication-essential enzymes, such as RNA-dependent RNA polymerase, thus inhibiting viral replication. ${ }^{4}$ Viral proteases are well-validated drug targets for treating human immunodeficiency virus and hepatitis $\mathrm{C}$ virus and have been used in various approved oral drugs. ${ }^{5}$ Additionally, the antiviral efficacy of the $3 \mathrm{CL}^{\text {pro }}$ inhibitor would likely be unaffected by and not induce mutations of the spike protein, which often occur in SARS-CoV-2 variants, because the $3 \mathrm{CL}^{\text {pro }}$ and spike protein are distinct proteins encoded in different regions of the viral genome. Thus, $3 \mathrm{CL}^{\text {pro }}$ is an attractive target for small-molecule oral therapeutics for treating COVID-19. Recent reports have revealed that peptide-like 3CL pro inhibitors with reactive "warheads" show potent antiviral activities in vitro, and some of these drugs reduced viral loads in vivo in SARS-CoV-2-infected human ACE2 transgenic mouse models. ${ }^{6,7}$ Recently, Pfizer reported good results from a clinical study of the peptidic, covalent oral 3CL $\mathrm{C}^{\text {pro }}$ inhibitor, PF-07321332, which is dosed with ritonavir as a pharmacokinetic (PK) 
booster. ${ }^{8}$ However, challenges remain for improving the target selectivity and PK profiles of peptide-like covalent inhibitors owing to the intrinsic nature of the reactivity, low membrane permeability and low metabolic stability. ${ }^{9-11}$ Hence, non-peptidic, non-covalent smallmolecule inhibitors have attracted much attention; however, their potency and PK profiles must be further optimized. ${ }^{12-16}$

Here, we describe the discovery of S-217622, the first non-peptidic, non-covalent SARSCoV-2 $3 \mathrm{CL}^{\text {pro }}$ inhibitor clinical candidate for treating COVID-19, and its preclinical characterization. S-217622 displayed antiviral activity in vitro towards a range of SARSCoV-2 variants and coronavirus families, favorable drug metabolism and pharmacokinetic (DMPK) profiles for the oral agents, and dose-dependent antiviral efficacy in vivo, indicating its potential for once-daily oral treatment of COVID-19.

\section{Results and Discussions}

To rapidly obtain the non-covalent SARS-CoV-2 $3 \mathrm{CL}^{\text {pro }}$ inhibitor clinical candidate to combat with the pandemic, we used a structure-based drug design (SBDD) strategy, starting with docking-based virtual screening followed by biological screening using an in-house compound library (Figure 1). First, we investigated pharmacophores in the binding site of $3 \mathrm{CL}^{\text {pro }}$ based on the interactions of known inhibitors because applying the pharmacophore filter to the docking screening helps enrich the virtual-screening hit rate. ${ }^{17} 3 \mathrm{CL}^{\text {pro }}$ is a cysteine protease with a Cys145-His41 catalytic dyad in its active site, which strongly recognizes P1 Gln and P2 Leu/Met/Phe/Val as its substrates. ${ }^{6}$ These substrate-like substructures are shared with the potent peptide-like inhibitors, GC- $376^{7}$ and N $3{ }^{18}$, a Gln-mimic lactam moiety in the 
S1 pocket and Leu-mimic hydrophobic moiety in the S2 pocket (Figure 2a). Non-covalent small-molecule inhibitors, such as ML188, ${ }^{12}$ ML300, ${ }^{13,14}$ and the 3-aminopyridine-like compound of the Postera COVID moonshot project, ${ }^{15,16}$ exhibit similar pharmacophores, which form a hydrogen bond with the side-chain NH donor of His163 in the S1 pocket and have fitted lipophilic moieties in the S2 pocket (Figure 2b, c). Additionally, the hydrogen bond with the Glu166 main-chain NH recognizes the P2 main-chain carbonyl of the substrate and is conserved in the known inhibitors. Given these interactions, we hypothesized that these three pharmacophores, i.e., the acceptor site with the side-chain NH donor of His 163 in the S1 pocket, the lipophilic site in the S2 pocket, and the acceptor site with the Glu166 mainchain $\mathrm{NH}$, play critical roles in small-molecule binding (Figure 2d).

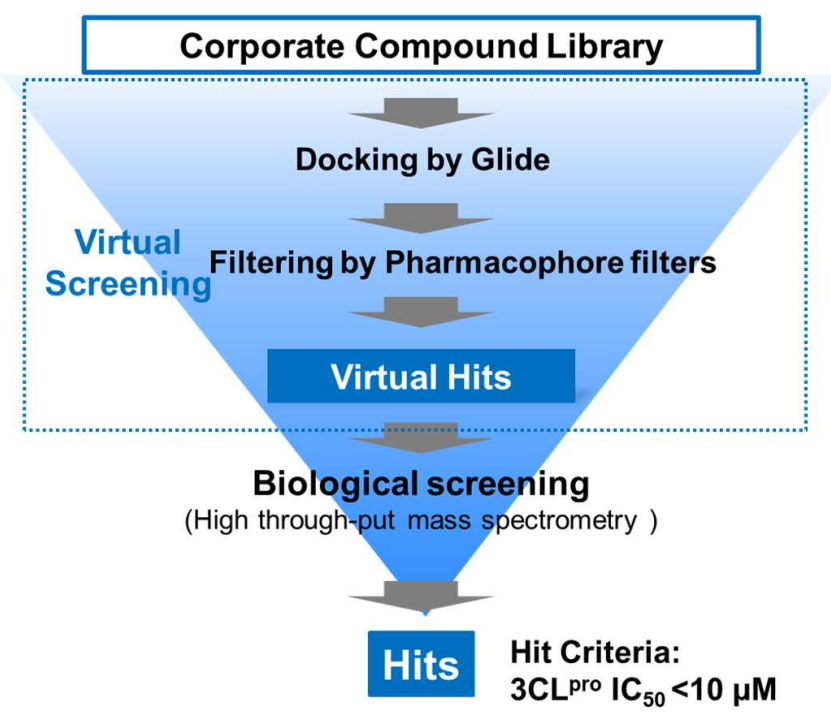

Figure 1. Schematic flow of the screening campaign. 

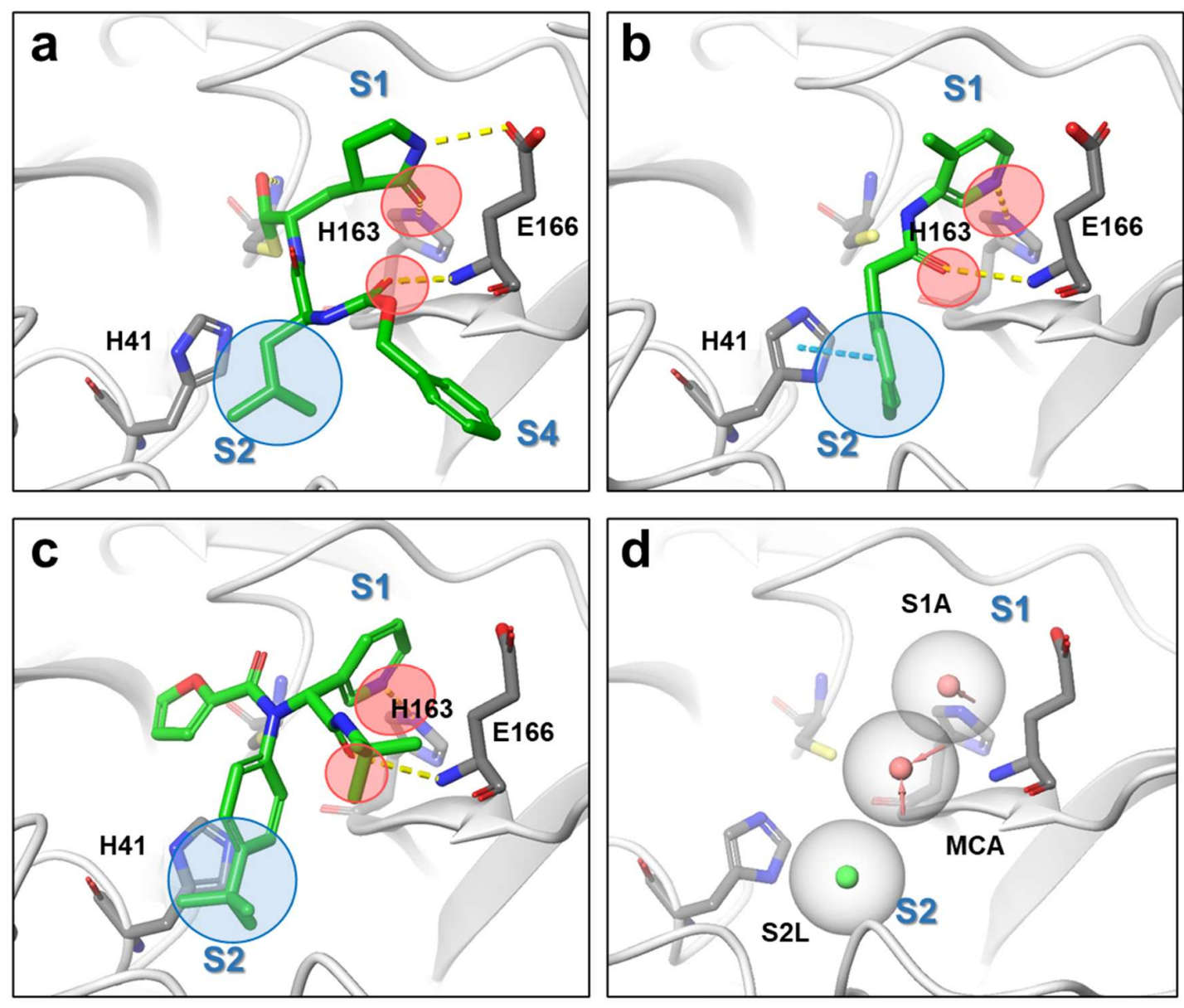

Figure 2. Binding modes of $3 \mathrm{CL}^{\text {pro }}$ inhibitors, their pharmacophores, and defined pharmacophore filters for virtual screening. (a) Crystal structures of GC376 (PDB: 6WTT), (b) 3-aminopyridine-like compound of the Postera COVID moonshot project (PDB: 5RH2) and (c) ML1 88 (PDB: 7L0D). The common H-bond acceptors are circled in red; the common hydrophobic pharmacophores are circled in blue. (d) Common pharmacophores shared with inhibitors A-C. Red and green spheres represent H-bond acceptors and lipophilic features, respectively. 
We performed docking-based virtual screening using the crystal structures of the $3 \mathrm{CL}^{\text {pro }}$ and ML188-like non-covalent small molecules (Protein Data Bank [PDB] code: 6w63). ${ }^{19}$ Compounds from the in-house library were docked, then the pharmacophore filter described above was applied to each docking pose, and the 300 top-scoring compounds were evaluated via enzymatic assays using mass spectrometry to avoid the false positives that frequently occur in fluorescence-based assays, giving some hit compounds with $\mathrm{IC}_{50}<10 \mu \mathrm{M}$.

Optimization of the PK profile is a common challenge in drug discovery and usually takes time to overcome. Therefore, if possible, potency optimization of a hit compound with favorable PK profiles is likely the most straightforward way to meet the urgent need for an oral $3 \mathrm{CL}^{\text {pro }}$ inhibitor. Further profiling of hit compounds revealed that one of the hit compounds, $\mathbf{1}$, could be a potential lead for this project because it displayed potent enzymatic inhibitory activity and favorable PK profiles with oral bioavailability (Figure 3). An enzymatic inhibition assay revealed that the $\mathrm{IC}_{50}$ value of 1 was $8.6 \mu \mathrm{M}$, and the in vitro metabolic stabilities of $\mathbf{1}$, measured after 30 min of incubation in human and rat microsomes, were $97 \%$ and $71 \%$, respectively. An in vivo PK study in rats demonstrated that $\mathbf{1}$ had a favorable profile for the oral agent, oral bioavailability $(F)$ of $111 \%$ and a low clearance of $7.3 \mathrm{~mL} / \mathrm{min} / \mathrm{mg}$. 


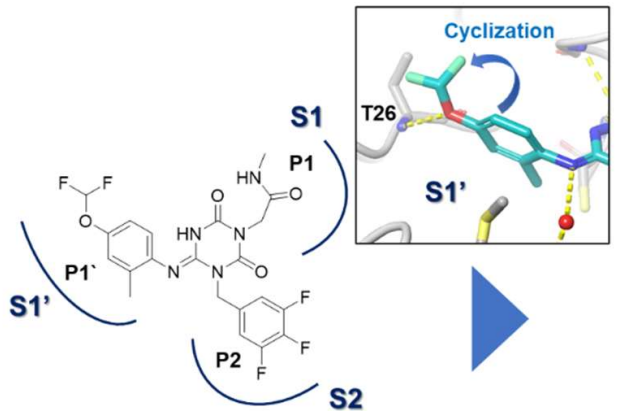

1 (Screening Hit)

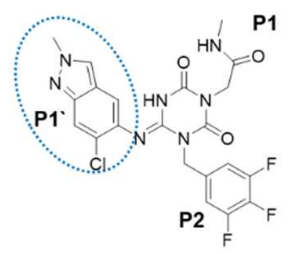

2

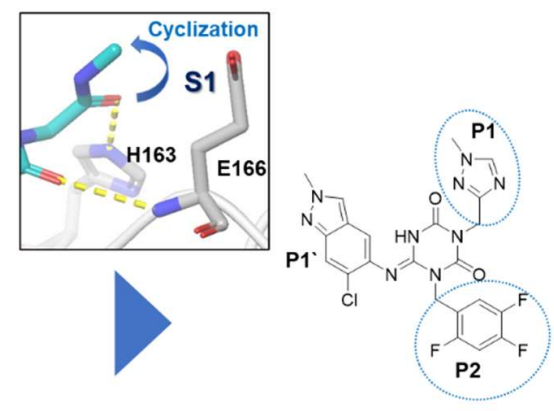

3 (S-217622)

\begin{tabular}{|c|c|c|c|c|c|c|}
\hline Compound & $\begin{array}{c}\text { SARS-CoV-2 3CLpro } \\
\text { IC50 }(\mu \mathrm{M})\end{array}$ & $\begin{array}{c}\text { VeroE6/TMPRSS2 }{ }^{\mathrm{a}} \\
\text { EC50 }(\mu \mathrm{M})\end{array}$ & HLM / RLM (\%) & $\begin{array}{l}\mathrm{CL}^{\mathrm{d}}(\mathrm{mL} / \mathrm{min} / \mathrm{kg}) \\
\text { rat }^{\prime} / \mathrm{monkey}^{1} / \mathrm{dog}^{1}\end{array}$ & $\begin{array}{c}t_{1 / 2}(\mathbf{h}) \\
\text { ratg/monkey//dog }\end{array}$ & $\begin{array}{c}\text { Oral F (\%)e } \\
\text { rat }{ }^{\mathrm{h}} / \text { monkey }{ }^{\mathrm{j}, \mathrm{k} / \text { dog }^{\mathrm{j}, \mathrm{k}}}\end{array}$ \\
\hline 1 & 8.6 & $N T^{f}$ & $97.1 / 70.8$ & 7.3/NT $/ \mathrm{NT}^{\mathrm{f}}$ & $2.1 / N T^{f} / N T^{f}$ & $111 / N T^{f} / N T^{f}$ \\
\hline 2 & 0.096 & 12.5 & $94.8 / 94.3$ & $4.9 / \mathrm{NT}^{\mathrm{f}} / \mathrm{NT}^{\mathrm{f}}$ & $1.3 / \mathrm{NT}^{\mathrm{f}} / \mathrm{NT}^{f}$ & $29.6 / N T^{f} / N T^{f}$ \\
\hline 3 (S-217622) & $0.013^{k}$ & $0.37^{\mathrm{k}}$ & $96.0 / 88.2$ & $1.7 / 0.29 / 0.17$ & $2.4 / 10.0 / 29.5$ & $96.7 / 106 / 64.7$ \\
\hline
\end{tabular}

Figure 3. Structure-based optimization of hit compound 1 and profiles of the compounds. ${ }^{\mathrm{a} C y t o p a t h i c ~ e f f e c t ~ i n h i b i t i o n ~ a s s a y ~ w i t h ~ V e r o ~ E 6 ~ c e l l s ~ e x p r e s s i n g ~ h u m a n ~ t r a n s m e m b r a n e ~}$ protease serine 2 (VeroE6/TMPRSS2). b\% remaining in human liver microsomes (HLMs) after $30 \mathrm{~min} .{ }^{\mathrm{c}} \%$ remaining in rat liver microsomes (RLMs) after $30 \mathrm{~min} .{ }^{\mathrm{d}}$ Total clearance, ${ }^{\mathrm{e}}$ Oral bioavailability. ${ }^{\mathrm{f}}$ Not tested. ${ }^{\mathrm{g}}$ Intravenously administered $0.5 \mu \mathrm{mol} / \mathrm{mL} / \mathrm{kg}(\mathrm{n}=2)$, nonfasted; ${ }^{\mathrm{h}}$ Orally administered $1 \mu \mathrm{mol} / 5 \mathrm{~mL} / \mathrm{kg}(\mathrm{n}=2)$, non-fasted; ${ }^{i}$ Intravenously administered $0.1 \mathrm{mg} / 0.2 \mathrm{~mL} / \mathrm{kg}(\mathrm{n}=2)$, non-fasted; jOrally administered $3 \mathrm{mg} / 2 \mathrm{~mL} / \mathrm{kg}(\mathrm{n}=3)$, non-fasted. ${ }^{\mathrm{k}}$ Evaluated as S-217622 fumaric acid co-crystal form.

We resolved the X-ray complex structure of 1 with the protease (Figure 4a). As expected, the binding mode of $\mathbf{1}$ in the X-ray structure was similar to that obtained in the docking 
(Figure 4b). The S1 and S2 pockets were filled with the methyl-amide and 3,4,5trifluorobenzene moieties, respectively. The 4-difluoromethoxy-2-methylbenzene subunit was placed in the S1' pocket. The 2-carbonyl oxygen of the center triazine moiety formed a hydrogen bond with the main-chain NH of Glu166. The other side of the 4-carbonyl oxygen was bound in the oxyanion hole of the protease, which formed two hydrogen bonds with the main-chain NHs of Gly143 and Cys145. The methyl-amide moiety was placed in the S1 pocket, of which, the carbonyl oxygen interacted with the side-chain $\mathrm{NH}$ of His163. The protease exhibited an interesting conformational change in the S2 pocket; the side chain of the catalytic His41 was rotated and formed a face-to-face $\pi$ interaction with the 3,4,5trifluorobenzene moiety of $\mathbf{1}$, whereas the docking pose predicted an edge-to-face $\pi$ interaction (Figure 4c,d). Along with the side-chain flip of His41, the 4-difluoromethoxy-2methylbenzene fragment was placed in a slightly different site compared with that of the docking pose, in which the ether oxygen of the P1' ligand formed a hydrogen bond with the main-chain $\mathrm{NH}$ of Thr26. An imine linker formed a water-mediated hydrogen bond with the His41 side chain, indicating its contribution to the affinity. 

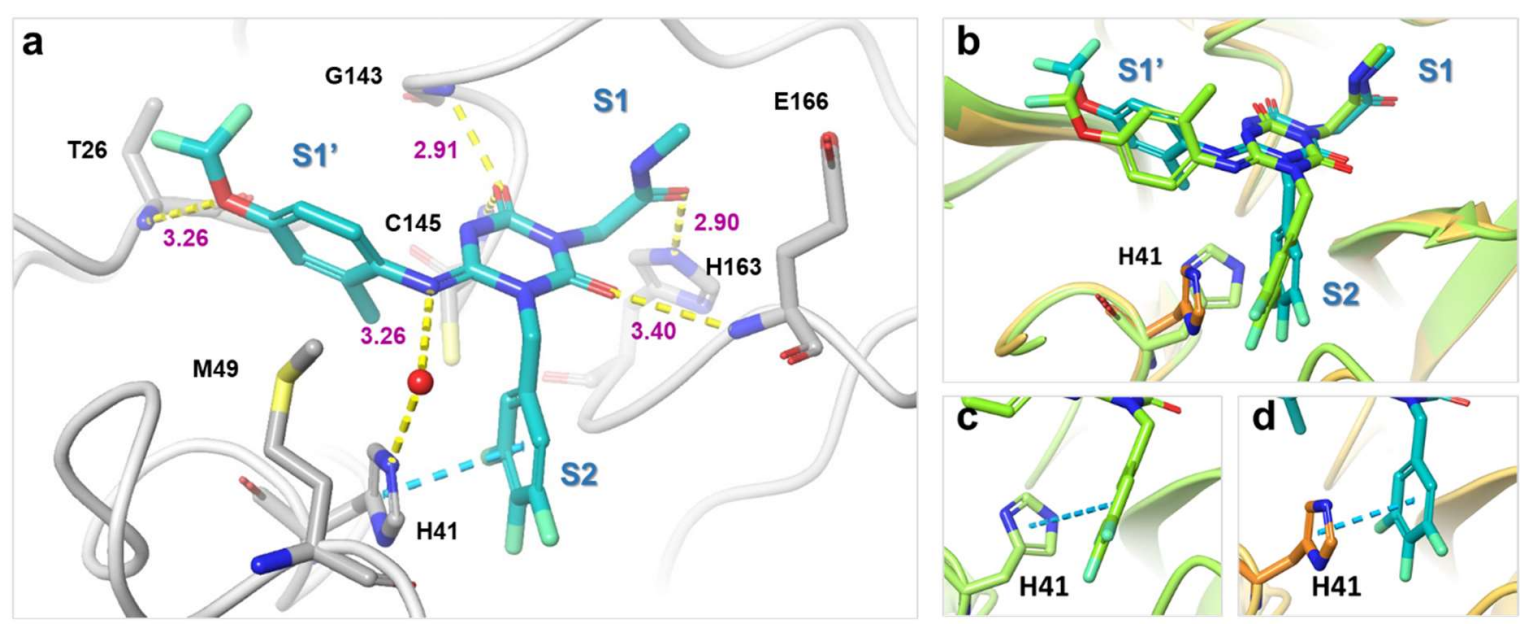

Figure 4. X-ray co-structure of hit compound 1 and $3 \mathrm{CL}^{\mathrm{pro}}$. (a) Close-up view of $\mathbf{1}$ (cyan) in the binding pocket. Water molecules are shown as red spheres. Hydrogen bonds are indicated as yellow dashed lines; $\pi-\pi$ stacking is indicated as a cyan dashed line. (b-d) Comparison of a docking pose and X-ray crystal structure of 1 . Near the S2 pocket, the sidechain of His41 was rotated to form a face-to-face $\pi$ interaction with the 3,4,5-trifluorobenzene moiety of $\mathbf{1}$. Docked structure is in lime green, and the X-ray structure is in cyan (1) and orange (protein residues).

Keeping the hydrogen bonds confirmed by the X-ray complex structure, straightforward multiparameter optimization was achieved starting from hit compound 1 (Figure 3). First, for a better fit with the S1' pocket, we optimized the $\mathrm{P} 1$ ' ligand while keeping the hydrogen bond with Thr26. As a result, compound 2, having 6-chloro-2-methyl-2 $H$-indazole as a P1' ligand, displayed a 90-fold improvement in enzymatic inhibitory activity while maintaining the favorable DMPK profile. Next, the P1 methyl-amide moiety was replaced with a range of heterocyclic compounds, thus yielding compound $\mathbf{3}$, which eventually became the clinical 
candidate, S-217622. S-217622 showed a biochemical activity of $\mathrm{IC}_{50}=0.013 \mu \mathrm{M}$, an antiviral activity of $\mathrm{EC}_{50}=0.37 \mu \mathrm{M}$, and preferable DMPK profiles for oral dosing, such as high metabolic stability ( $96 \%$ and $88 \%$ in human and rat liver microsomes, respectively), high oral absorption $(97 \%)$ and low clearance $(1.70 \mathrm{~mL} / \mathrm{min} / \mathrm{mg})$ in rats (Figure 3, Tables S1-S3). Furthermore, S-217622 showed even better DMPK profiles in monkeys and dogs than in rats, with low clearance, long half-lives $\left(t_{1 / 2}\right)$ of approximately 10 and 30 hours in monkeys and dogs, respectively, and high oral bioavailability for all animals tested, suggesting its potential use for once-daily treatment of COVID-19 without requiring a PK booster such as ritonavir.

Figure 5 shows the X-ray co-crystal structure of $3 \mathrm{CL}^{\text {pro }}$ complexed with S-217622. In the S1 site, the 1-methyl-1H-1,2,4-triazole unit fit to the $\mathrm{S} 1$ pocket, forming a hydrogen bond with the side-chain $\mathrm{NH}$ of His 163. The distinctive His41 flip observed in $\mathbf{1}$ was maintained in the S-217622 complex, and the 2,4,5-trifluorobenzylic moiety occupied the hydrophobic $\mathrm{S} 2$ pocket and stacked with the side chain of His41. The P1' ligand, 6-chloro-2-methyl- $\mathrm{H}$ indazole moiety held hydrogen bonding with the Thr26 main-chain $\mathrm{NH}$ and hydrophobic contact with Met49 as seen in the co-crystal structure of $\mathbf{1}$. 


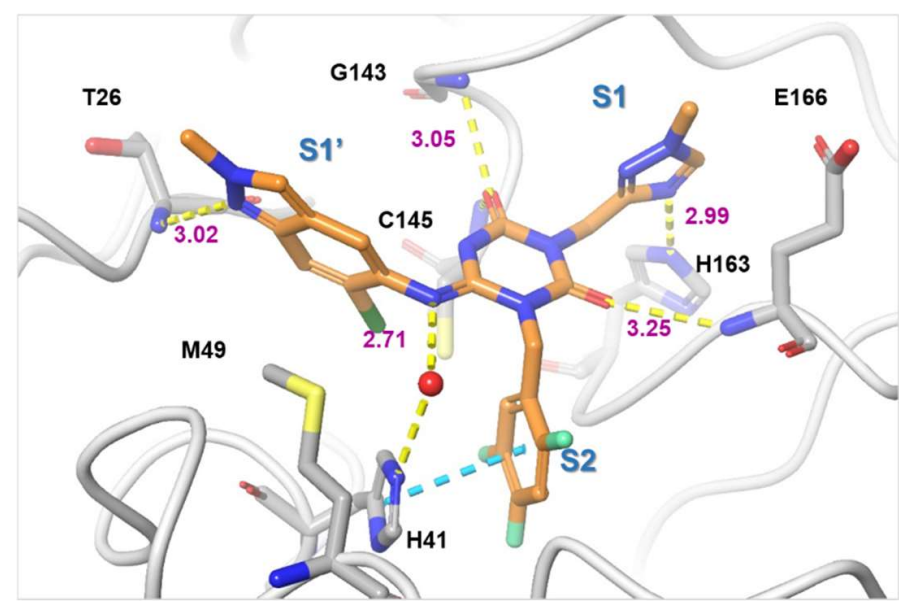

Figure 5. X-ray co-structure of S-217622 (3) and $3 \mathrm{CL}^{\text {pro }} .3$ is colored in orange and the protein is colored in gray. Water molecules are shown as red spheres. Hydrogen bonds are indicated as yellow dashed lines; $\pi-\pi$ stacking is indicated as a cyan dashed line.

Figure 6 summarizes the in vitro antiviral activities of S-217622 against several clinically isolated SARS-CoV-2 variants and family of coronaviruses. The antiviral activities were evaluated as per their inhibitory ability of the cytopathic effects elicited in SARS-CoV-2infected VeroE6/TMPRSS2 cells. S-217622 exhibited similar antiviral activities against all tested SARS-CoV-2 variants, including the omicron strain, which has caused the current wave of the pandemic, indicating its potential broad usability as a therapeutic agent for treating COVID-19 (half-maximal effective concentration [EC $\mathrm{E}_{50}$ ]: 0.29-0.50 $\mu \mathrm{M}$; Figure 6a, Tables S2, S3). Because no significant mutations have been reported near the catalytic center of $3 \mathrm{CL}^{\text {pro }}$ in these variants of concern, orthosteric $3 \mathrm{CL}^{\text {pro }}$ inhibitors should be effective against all strains known to date. Antiviral activity of S-217622 against SARS-CoV (EC 50 : $0.21 \mu \mathrm{M}$, Figure $6 \mathrm{~b}$ ) was also comparable to that against SARS-CoV-2, where the sequence homology of $3 \mathrm{CL}^{\text {pro }}$ between SARS-CoV-2 and SARS-CoV was well conserved. S-217622 
(3) also exhibited potent antiviral activity against MERS-CoV (EC50:1.4 $\mu \mathrm{M}$, Figure. $6 \mathrm{c}$ ), HCoV-OC43 (EC90: $0.074 \mu \mathrm{M}$, Figure 6e) and HCoV-229E (EC ${ }_{50}: 5.5 \mu \mathrm{M}$, Figure 6d). As described above, S-217622 displayed broad antiviral activities against a range of coronaviruses, suggesting possible applications of this compound or its derivatives for the next pandemic caused by future emerging coronaviruses. S-217622 showed no inhibitory activity against host-cell proteases, such as caspase-2, chymotrypsin, cathepsin $\mathrm{B} / \mathrm{D} / \mathrm{G} / \mathrm{L}$, and thrombin at up to $100 \mu \mathrm{M}$, suggesting its high selectivity for coronavirus proteases (Table 1). S-217622 (3) exhibited no safety concerns in vitro in studies involving ether-a-go-go-related gene inhibition, mutagenicity/clastogenicity, and phototoxicity (Table S4).
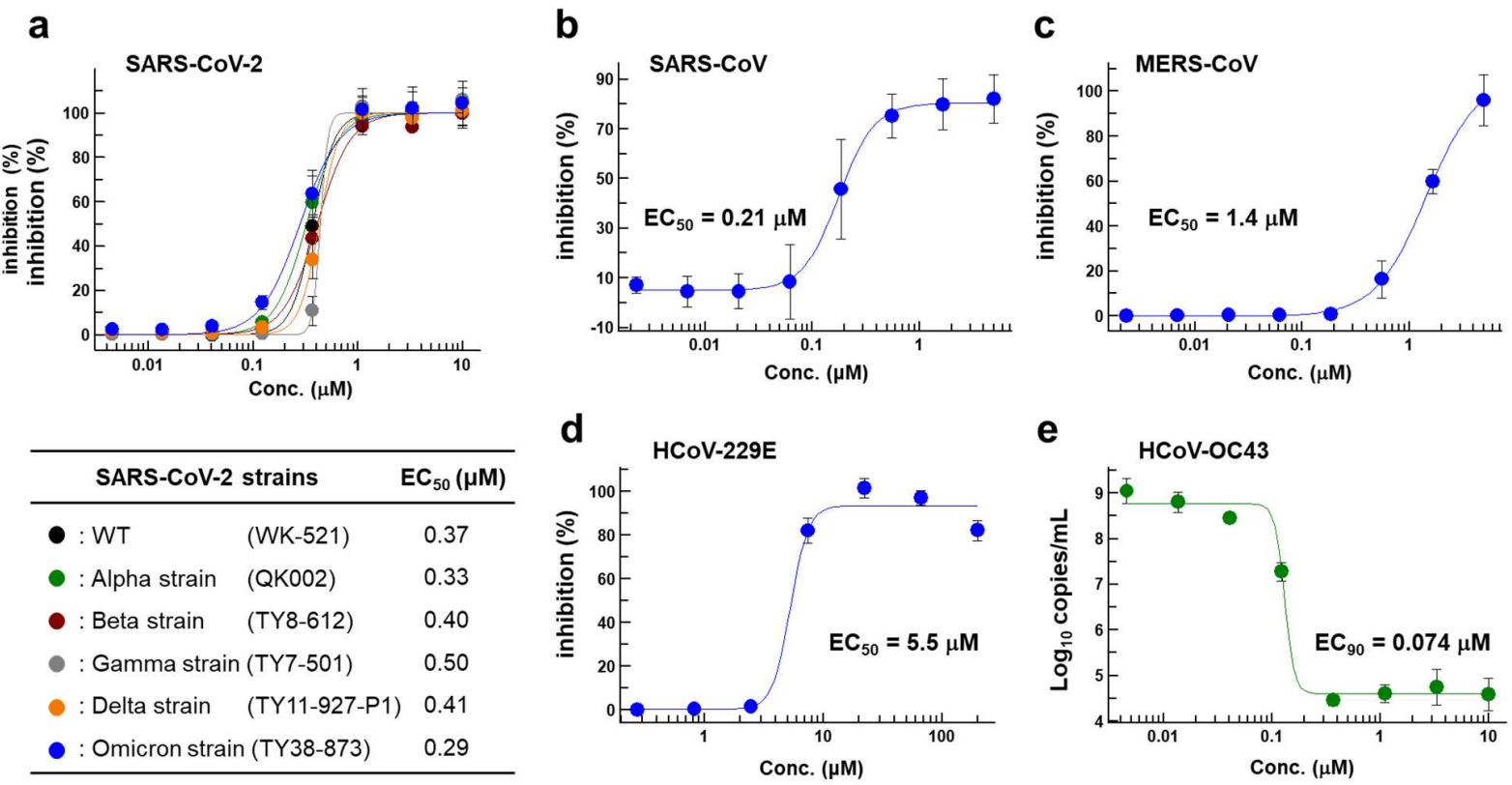

Figure 6. In vitro cellular activity of S-217622. Antiviral activity of S-217622 (fumaric acid co-crystal) against (a) various SARS-CoV-2 strains, (b) SARS-CoV, and (c) MERS-CoV in a cytopathic effect (CPE) inhibition assay using VeroE6/TMPRSS2 cells. Antiviral activity 
of S-217622 against (d) HCoV-229E (Alphacoronavirus) in a CPE inhibition assay with MRC-5 cells, and (e) HCoV-OC43 (Betacoronavirus) in a real-time quantitative reverse transcription polymerase chain reaction (RT-qPCR) assay with MRC-5 cells. Data are the means \pm standard deviation; $\mathrm{n}=3$ biological replicates for SARS-CoV-2 strains, MERS-CoV, HCoV-229E, and HCoV-OC43 and $n=4$ for SARS-CoV.

\begin{tabular}{cc}
\hline Protease & IC $_{50}(\boldsymbol{\mu M})$ \\
\hline Caspase 2 & $>100$ \\
Chymotrypsin & $>100$ \\
Chathepsin B & $>100$ \\
Chathepsin D & $>100$ \\
Chathepsin G & $>100$ \\
Chathepsin L & $>100$ \\
Thorombin & $>100$ \\
HIV-1 Protease & $>100$ \\
\hline
\end{tabular}

Table 1. Enzymatic inhibitory activity of S-217622 against human host proteases and an HIV-1 protease. Inhibitory activities were $<50 \%$ at $100 \mu \mathrm{M}$.

We evaluated the antiviral efficacy of S-217622 in vivo in mice infected with SARS-CoV2 Gamma strain (Figure 7). K417T, E484K, and N501Y mutations at the receptor-binding domain of the spike protein in SARS-CoV-2 Gamma strain promote interactions with mouse ACE2. ${ }^{20}$ Five-week-old BALB/c mice were intranasally inoculated with SARS-CoV-2 Gamma strain (hCoV-19/Japan/TY7-501/2021), and S-217622 (3) was administered orally as a $0.5 \%$ methylcellulose suspension immediately and twelve hours after infection (Figure 
7a). Twenty-four hours after viral infection, the mice were euthanized, and the viral titers in their lung homogenates were measured. S-217622 (3) treatment reduced the intrapulmonary viral titers dose-dependently (Figure 7b). The mean viral titer was significantly lower in the S-217622 (3) treatment groups than in the vehicle treatment group $(2 \mathrm{mg} / \mathrm{kg}$ vs vehicle, $\mathrm{p}=$ $0.0289 ; 8,16$ and $32 \mathrm{mg} / \mathrm{kg}$ vs vehicle, $\mathrm{p}<0.0001)$. Viral titers reached near the lower limit of quantification $\left(1.80-\log _{10} 50 \%\right.$ tissue culture infectious dose $\left.\left[\mathrm{TCID}_{50}\right] / \mathrm{mL}\right)$ at 16 and 32 $\mathrm{mg} / \mathrm{kg}$ in the S-217622 (3) treatment group. The plasma concentration increased dosedependently between 2 and $32 \mathrm{mg} / \mathrm{kg}$ in the infected mice (Figure. $7 \mathrm{c}$ ), and at doses of $\geq 16$ $\mathrm{mg} / \mathrm{kg}$, the plasma concentration was estimated to be above the protein-adjusted-EC ${ }_{50}$ (PA$\mathrm{EC}_{50}$ ) value (extrapolated to $100 \%$ mouse serum, $3.93 \mu \mathrm{mol} / \mathrm{L}=2,090 \mathrm{ng} / \mathrm{mL}$ ) over time, indicating the importance of the free plasma concentration for in vivo efficacy (Figure 7d). Although we applied twice-daily treatment in this mouse model, a once-daily treatment model could be applicable in clinical treatment because S-217622 showed a much lower clearance and longer half-lives in non-rodents than in rodents (Figure 3). 


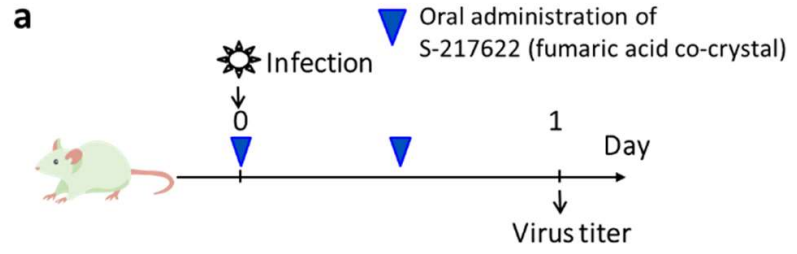

- Animal: Mice (female, BALB/c, 5 weeks old)

- Virus: SARS-CoV-2 Gamma strain $\left(1 \times 10^{4} \mathrm{TCID}_{50} /\right.$ mouse $)$

- Dosing: Oral administration, bid (immediately and 12 hours after virus infection)

- Virus titer in the lung: 24 hours after virus infection

\section{c}

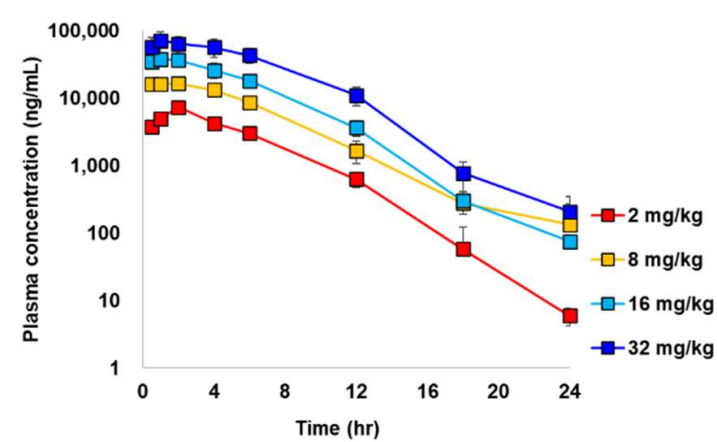

b

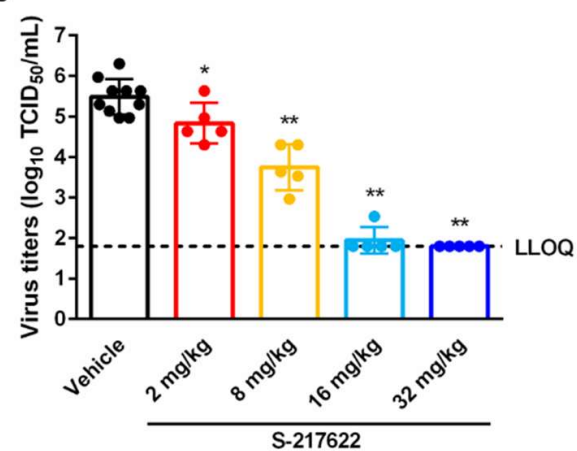

d

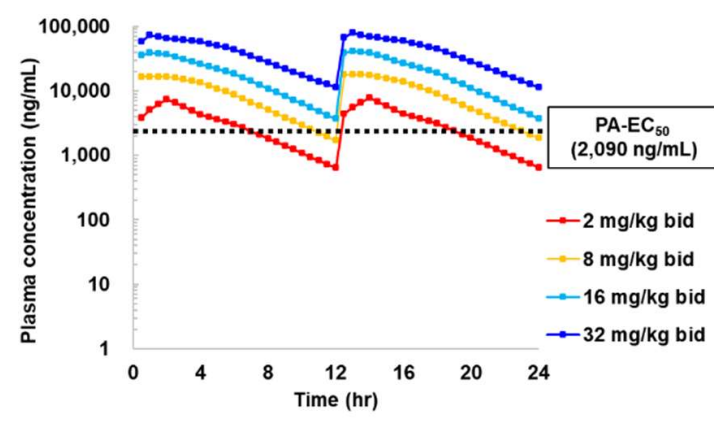

Figure 7. Dose-dependent in vivo antiviral efficacy of S-217622 in mice infected with SARS-

CoV-2. (a) Protocol for the in vivo study. bid = twice a day; (b) Effect of S-217622 (fumaric acid co-crystal) treatment on lung viral titers in SARS-CoV-2 Gamma strain (hCoV19/Japan/TY7-501/2021)-infected mice. TCID $_{50}=50 \%$ tissue culture infectious dose; each point represents an individual viral titer $(n=5-10)$. The broken line represents the lower limit of quantification $\left(1.80 \log _{10} \mathrm{TCID}_{50} / \mathrm{mL}\right)$. The following $p$-values were calculated using Dunnett's test: $* p<0.05$ and ${ }^{* *} p<0.0001$ vs vehicle. (c) S-217622 plasma concentration in the infected mice $(n=4)$. (d) Simulated S-217622 plasma concentrations after repeated oral administration of S-217622 (fumaric acid co-crystal) twice daily in infected mice as per non-parametric superposition. $\mathrm{PA}-\mathrm{EC}_{50}=$ protein-adjusted $\mathrm{EC}_{50}$ extrapolated to $100 \%$ mouse 
serum.

\section{Chemistry}

The synthetic scheme for compound $\mathbf{1}$ is described in Scheme 1. Starting from the pyrazole derivative 4, cyclization with Ethyl isocyanatoacetate and CDI was conducted, giving 5 in 90\% yield. Then, an alkylation with 5-bromomethyl-1,2,3-trifluorobenzene followed by introduction of a 4-difluoromethoxy-2-methylaniline unit, to give 7 (40\% in 2 steps). The ester group in 7 was hydrolyzed and then amidated with methylamine, yielding 1 ( $58 \%$ in 2 steps). Compound 2 was synthesized similarly as shown in Scheme 2.

S-217622 (3) was synthesized as described in Scheme 3. Starting from known compound $\mathbf{9},{ }^{21}$ an alkylation with 1-(bromomethyl)-2,4,5-trifluorobenzene gave $\mathbf{1 0}$ in $93 \%$ yield. Then, the 3-tert-Bu group was removed and the triazole unit was introduced, and the substitution of the SEt moiety with the indazole unit finally gave S-217622 (3).<smiles>CCOC(=O)Cn1c(=O)nc(-n2cccn2)[nH]c1=O</smiles><smiles>CCOC(=O)Cn1c(=O)[nH]c(=Nc2ccc(OC(F)F)cc2C)n(Cc2ccc(F)c(F)c2)c1=O</smiles><smiles>CNC(=O)CC(=O)n1c(=O)[nH]c(=Nc2ccc(OC(F)F)cc2C)n(Cc2ccc(F)c(F)c2)c1=O</smiles>

Scheme 1. Reagents and Conditions: (a) ethyl isocyanato-acetate, DBU, CDI, DMA, $-10{ }^{\circ} \mathrm{C}$ 
to rt, 90\%; (b) 5-bromomethyl-1,2,3-trifluorobenzene, $N, N$-diisopropylethylamine, DMA, $60{ }^{\circ} \mathrm{C}$; (c) 4-difluoromethoxy-2-methylaniline, tert-butanol, $100{ }^{\circ} \mathrm{C}, 40 \%$ in 2 steps; (d) (i) $\mathrm{NaOH}$ aq., THF/MeOH, rt; (ii) methylamine, HATU, $N, N$-diisopropylethylamine, THF, rt., $58 \%$ in 2 steps.
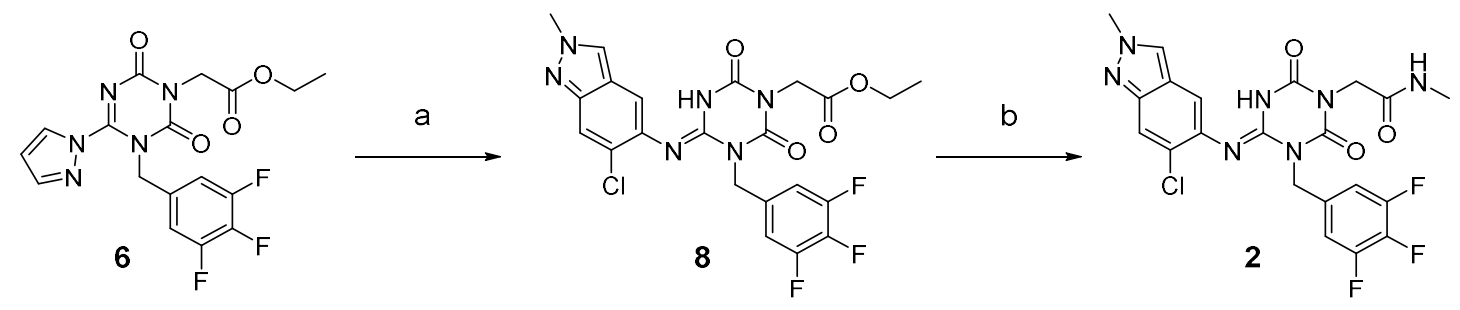

Scheme 2. Reagents and Conditions: (a) 6-chloro-2-methyl-2H-indazol-5-amine, tert-amyl alcohol, $100{ }^{\circ} \mathrm{C}, 44 \%$ in 2 steps from 5; (b) (i) $\mathrm{NaOH}$ aq., THF/MeOH, rt; (ii) methylamine, HATU, $N, N$-diisopropylethylamine, THF, rt., 29\% in 2 steps. 


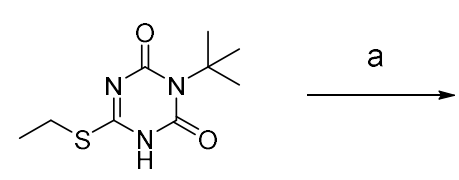

9

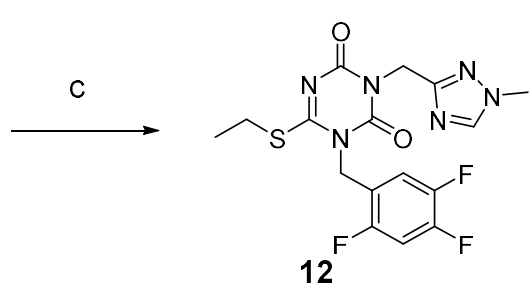

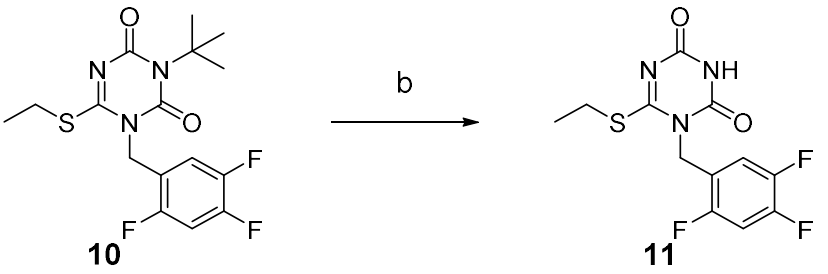

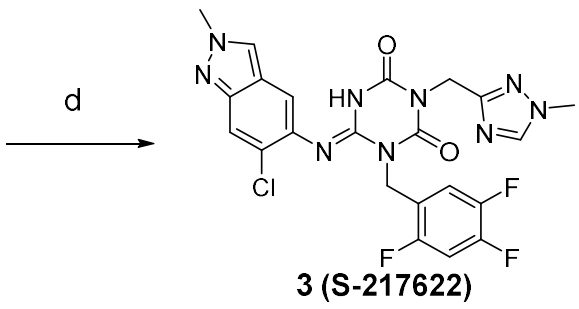

Scheme 3. Reagents and Conditions: (a) 1-(bromomethyl)-2,4,5-trifluorobenzene, $\mathrm{K}_{2} \mathrm{CO}_{3}$, $\mathrm{MeCN}, 80{ }^{\circ} \mathrm{C}, 93 \%$; (b) TFA, rt, 97\%; (c) 3-(chloromethyl)-1-methyl-1H-1,2,4-triazole hydrochloride, $\mathrm{K}_{2} \mathrm{CO}_{3}$, DMF, $60{ }^{\circ} \mathrm{C}, 45 \%$; (d) 6-chloro-2-methyl-2H-indazol-5-amine, LHMDS, THF, $0{ }^{\circ} \mathrm{C}$ to rt., $25 \%$.

\section{Conclusions}

Here, we described the discovery of S-217622, the first non-peptidic, non-covalent, oral $3 \mathrm{CL}^{\text {pro }}$ inhibitor clinical candidate for treating COVID-19. When we started this discovery program, most of the known inhibitors were peptide substrate mimetics with covalent warheads that bound covalently to Cys 145 in the active site of $3 \mathrm{CL}^{\text {pro }}$. We assumed that these peptidic and reactive structural features would cause problems in the DMPK profile, such as low oral bioavailability due to low cell permeability, low metabolic stability, and low stability in the blood serum. Thus, we began the de novo search for non-peptidic $3 \mathrm{CL}^{\text {pro }}$ inhibitors using the SBDD strategy to combat the current SARS-CoV-2 pandemic. Virtual screening followed by biological screening yielded several hit compounds with $\mathrm{IC}_{50}$ values $<10 \mu \mathrm{M}$, 
and one of these hit compounds, compound 1, showed a favorable DMPK profile for an oral agent. Using the X-ray co-structure, SBDD-based structural optimization enabled $>600$-fold activity improvement while maintaining a good DMPK profile; this ultimately yielded the drug candidate, S-217622 (3). S-217622 (3) exhibited a favorable preclinical profile as a once-daily oral therapeutic agent for COVID-19 with promising antiviral activities to known variants of concern, a long half-life in vivo, especially in monkeys and dogs, excellent oral bioavailability, and steep efficacy in an in vivo mouse model infected with SARS-CoV-2. These favorable profiles prompted us to progress S-217622 to clinical trials, and studies are ongoing. 


\section{Experimental section}

General Chemistry. All commercial reagents and solvents were used as received without further purification. Reactions were monitored via thin-layer chromatography performed on Merck silica gel plates (60 F254) or analytical liquid chromatography/mass spectroscopy (LC/MS) performed on a Shimadzu Shim-pack XR-ODS $(\mathrm{C} 18,2.2 \mu \mathrm{m}, 3.0 \times 50 \mathrm{~mm}$, linear gradient from $10 \%$ to $100 \% \mathrm{~B}$ over $3 \mathrm{~min}$, then $100 \% \mathrm{~B}$ for $1 \mathrm{~min}[\mathrm{~A}=$ water $+0.1 \%$ formic acid, $\mathrm{B}=\mathrm{MeCN}+0.1 \%$ formic acid], flow rate: $1.6 \mathrm{~mL} / \mathrm{min}$ ) using a Shimadzu UFLC system equipped with a LCMS-2020 mass spectrometer, LC-20AD binary gradient module, SPDM20A photodiode array detector (detection at $254 \mathrm{~nm}$ ), and SIL-20AC sample manager. All compounds used in the bioassay are $>95 \%$ pure by HPLC analysis. Flash column chromatography was performed on an automated purification system using Fuji Silysia prepacked silica gel columns. ${ }^{1} \mathrm{H}$ and ${ }^{13} \mathrm{C}$ NMR spectra were recorded on a Bruker Advance at 400 and $100 \mathrm{MHz}$, respectively. Spectral data are reported as follows: chemical shift (as ppm referenced to tetramethylsilane), integration value, multiplicity ( $\mathrm{s}=$ singlet, $\mathrm{d}=$ doublet, $\mathrm{t}=$ triplet, $\mathrm{q}=$ quartet, $\mathrm{m}=$ multiplet, $\mathrm{br}=$ broad), and coupling constant. High-resolution mass spectra were recorded on a Thermo Fisher Scientific LTQ Orbitrap using electrospray positive ionization.

Ethyl 2-[2,6-dioxo-4-(1H-pyrazol-1-yl)-3,6-dihydro-1,3,5-triazin-1(2H)-yl]acetate (5) 
To a stirred solution of $1 H$-pyrazole-1-carboximidamide hydrochloride 4 (53.5 g, 365 mmol) in DMA (214 mL) were added ethyl isocyanatoacetate $(49.5 \mathrm{~g}, 383 \mathrm{mmol})$ and DBU (57.8 $\mathrm{mL}, 383 \mathrm{mmol}$ ) below $-10^{\circ} \mathrm{C}$. The reaction mixture was allowed to warm to $0{ }^{\circ} \mathrm{C}$ and stirred for $30 \mathrm{~min}$ at the same temperature. CDI $(89.0 \mathrm{~g}, 548 \mathrm{mmol})$ and DBU $(85.0 \mathrm{~mL}, 566 \mathrm{mmol})$ were added to the mixture below $10{ }^{\circ} \mathrm{C}$. After stirring at room temperature overnight, the reaction mixture was quenched with aqueous $2 \mathrm{M} \mathrm{HCl}(1000 \mathrm{~mL})$. The solid was filtered, washed with $\mathrm{H}_{2} \mathrm{O}$ to afford 5 (86.8 g, 90\%) as a white solid. ${ }^{1} \mathrm{H}$ NMR (400 MHz, DMSO- $d_{6}$ ) $\delta 1.21(3 \mathrm{H}, \mathrm{t}, J=7.1 \mathrm{~Hz}), 4.15(2 \mathrm{H}, \mathrm{q}, J=7.1 \mathrm{~Hz}), 4.52(2 \mathrm{H}, \mathrm{s}), 6.74(1 \mathrm{H}, \mathrm{dd}, J=2.9,1.5$ $\mathrm{Hz}), 8.08(1 \mathrm{H}, \mathrm{d}, J=1.0 \mathrm{~Hz}), 8.59(1 \mathrm{H}, \mathrm{dd}, J=2.9 \mathrm{~Hz}) .{ }^{13} \mathrm{C}$ NMR $\left(100 \mathrm{MHz}\right.$, DMSO- $\left.d_{6}\right) \delta$ 14.03, 42.19, 61.24, 111.38, 130.47, 145.82, 151.32, 152.12, 167.64. HRMS-ESI (m/z): [M $+\mathrm{H}]^{+}$calcd for $\left[\mathrm{C}_{10} \mathrm{H}_{12} \mathrm{~N}_{5} \mathrm{O}_{4}\right]^{+}$266.0877; found 266.0884.

Ethyl (4E)-2-(4-\{[4-(difluoromethoxy)-2-methylphenyl]imino\}-2,6-dioxo-3-(3,4,5trifluorobenzyl)-1,3,5-triazinan-1-yl)acetate (7)

A mixture of 5 (1.06 g, $4.00 \mathrm{mmol}), N, N$-diisopropylethylamine (0.907 mL, $5.20 \mathrm{mmol})$, and 5-bromoethyl-1,2,3-trifluorobenzene $(0.631 \mathrm{~mL}, 4.80 \mathrm{mmol})$ in DMA $(10 \mathrm{~mL})$ was stirred at $60{ }^{\circ} \mathrm{C}$ for $5 \mathrm{~h}$. Then, the reaction mixture was cooled to room temperature, and diluted with $\mathrm{H}_{2} \mathrm{O}$ and EtOAc. The aqueous layer was extracted with EtOAc. The organic layer was washed with $\mathrm{H}_{2} \mathrm{O}$ and brine, dried over $\mathrm{MgSO}_{4}$, and concentrated under reduced pressure to afford a crude product of 6 (1.65 g). After a mixture of 6 (268 mg, $\leq 0.665 \mathrm{mmol})$ and 4(difluoromethoxy)-2-methylaniline $(0.094 \mathrm{~mL}, 0.665 \mathrm{mmol})$ in tert-butanol $(2.7 \mathrm{~mL})$ was 
stirred at $100{ }^{\circ} \mathrm{C}$ for $30 \mathrm{~min}$, the reaction mixture was allowed to cool to room temperature. The mixture was concentrated under reduced pressure. The residue was purified by silica gel column chromatography ( $n$-hexane/EtOAc, gradient, 15-33\% EtOAc) to afford 7 (134 mg, $40 \%$ over 2 steps) as a white solid. ${ }^{1} \mathrm{H}$ NMR $\left(400 \mathrm{MHz}, \mathrm{CDCl}_{3}\right) \delta 1.31(3 \mathrm{H}, \mathrm{t}, J=7.2 \mathrm{~Hz})$, $2.01(3 \mathrm{H}, \mathrm{s}), 4.26(2 \mathrm{H}, \mathrm{q}, J=7.2 \mathrm{~Hz}), 4.57(2 \mathrm{H}, \mathrm{s}), 5.17(2 \mathrm{H}, \mathrm{s}), 6.48(1 \mathrm{H}, \mathrm{t}, J=74.0 \mathrm{~Hz})$, $6.72(1 \mathrm{H}, \mathrm{d}, J=8.5 \mathrm{~Hz}), 6.98(1 \mathrm{H}, \mathrm{dd}, J=8.5,2.4 \mathrm{~Hz}), 7.03(1 \mathrm{H}, \mathrm{d}, J=2.4 \mathrm{~Hz}), 7.19(2 \mathrm{H}, \mathrm{t}$, $J=7.3 \mathrm{~Hz}), 7.40(1 \mathrm{H}, \mathrm{br} \mathrm{s}) .{ }^{13} \mathrm{C} \mathrm{NMR}\left(100 \mathrm{MHz}, \mathrm{CDCl}_{3}\right) \delta 14.11,17.92,42.71,44.95,62.16$, $113.36(\mathrm{dd}, J=16.1,5.9 \mathrm{~Hz}), 115.95(\mathrm{t}, J=260 \mathrm{~Hz}), 118.88,121.78,122.97,132.09,132.03-$ $132.23(\mathrm{~m}), 136.80,139.52(\mathrm{dt}, J=251.9,15.2 \mathrm{~Hz}), 140.50,147.13,147.80(\mathrm{t}, J=2.9 \mathrm{~Hz})$, 149.46, $151.07(\mathrm{ddd}, J=250.2,9.5,3.7 \mathrm{~Hz}), 167.35$. HRMS-ESI $(\mathrm{m} / \mathrm{z}):[\mathrm{M}+\mathrm{H}]^{+}$calcd for $\left[\mathrm{C}_{22} \mathrm{H}_{20} \mathrm{~F}_{5} \mathrm{~N}_{4} \mathrm{O}_{5}\right]^{+}$515.1359; found 515.1348.

(4E)-2-(4-\{[4-(difluoromethoxy)-2-methylphenyl]imino\}-2,6-dioxo-3-(3,4,5trifluorobenzyl)-1,3,5-triazinan-1-yl)-N-methylacetamide (1)

A stirred solution of $7(100 \mathrm{mg}, 0.194 \mathrm{mmol})$ in $\mathrm{THF} / \mathrm{MeOH}(2 \mathrm{~mL}, \mathrm{v} / \mathrm{v}=1 / 1)$ was added $\mathrm{NaOH}(1 \mathrm{M}$ aqueous solution, $1.37 \mathrm{~mL}, 1.37 \mathrm{mmol})$ at room temperature. After stirring at room temperature for $2 \mathrm{~h}$, the reaction mixture was quenched with $1 \mathrm{M}$ aqueous $\mathrm{HCl}$ solution. The aqueous layer was extracted with EtOAc. The organic layer was washed with $\mathrm{H}_{2} \mathrm{O}$ and brine, dried over $\mathrm{MgSO}_{4}$, and concentrated under reduced pressure to afford a crude residue (71.1 mg). The residue $(71.1 \mathrm{mg}, \leq 0.146 \mathrm{mmol})$ in THF $(0.6 \mathrm{~mL})$ were added methylamine (2M in THF, $0.110 \mathrm{~mL}, 0.219 \mathrm{mmol}), N, N$-diisopropylethylamine $(0.077 \mathrm{~mL}, 0.439 \mathrm{mmol})$, 
and HATU $(83.0 \mathrm{mg}, 0.219 \mathrm{mmol})$. After stirring at room temperature overnight, the reaction mixture was diluted with $\mathrm{H}_{2} \mathrm{O}$ and EtOAc. The aqueous layer was extracted with EtOAc. The organic layer was washed with $\mathrm{H}_{2} \mathrm{O}$ and brine, dried over $\mathrm{MgSO}_{4}$, and concentrated under reduced pressure. The residue was purified by silica gel column chromatography $\left(\mathrm{CHCl}_{3} / \mathrm{MeOH}\right.$, gradient, $\left.0-10 \% \mathrm{MeOH}\right)$. The collected fraction was recrystallized from $n$ hexane/EtOAc to afford 1 (60.7 mg, 58\% over 2 steps) as a white solid. ${ }^{1} \mathrm{H}$ NMR (400 MHz, $\left.\mathrm{CDCl}_{3}\right) \delta 1.97(3 \mathrm{H}, \mathrm{s}), 2.86(3 \mathrm{H}, \mathrm{d}, J=4.8 \mathrm{~Hz}), 4.33(2 \mathrm{H}, \mathrm{s}), 5.13(2 \mathrm{H}, \mathrm{s}), 5.76(1 \mathrm{H}, \mathrm{d}, J=$ $4.8 \mathrm{~Hz}), 6.47(1 \mathrm{H}, \mathrm{t}, J=74.2 \mathrm{~Hz}), 6.68(1 \mathrm{H}, \mathrm{d}, J=8.3 \mathrm{~Hz}), 6.92(1 \mathrm{H}, \mathrm{dd}, J=8.3,2.4 \mathrm{~Hz})$, $6.97(1 \mathrm{H}, \mathrm{d}, J=2.4 \mathrm{~Hz}), 7.16(2 \mathrm{H}, \mathrm{t}, J=7.4 \mathrm{~Hz}), 8.15(1 \mathrm{H}$, br s$) .{ }^{13} \mathrm{C}$ NMR $(100 \mathrm{MHz}$, $\left.\mathrm{CDCl}_{3}\right) \delta 17.93,26.49,43.67,44.96,113.27(\mathrm{dd}, J=16.1,5.9 \mathrm{~Hz}), 116.18(\mathrm{t}, J=259.7 \mathrm{~Hz})$, $118.59,122.03,122.56,122.9,132.21,132.21-132.39(\mathrm{~m}), 136.83,139.44(\mathrm{dt}, J=252.4$, $15.0 \mathrm{~Hz}), 140.87,147.56(\mathrm{t}, J=2.9 \mathrm{~Hz}), 147.84,149.68,151.02(\mathrm{ddd}, J=250.2,10.3,3.7$ $\mathrm{Hz})$, 166.40. HRMS-ESI $(\mathrm{m} / \mathrm{z})$ : $[\mathrm{M}+\mathrm{H}]^{+}$calcd for $\left[\mathrm{C}_{21} \mathrm{H}_{19} \mathrm{~F}_{5} \mathrm{~N}_{5} \mathrm{O}_{4}\right]^{+}$500.1352; found 500.1348.

Ethyl (4E)-2-\{4-[(6-chloro-2-methyl-2H-indazol-5-yl)imino]-2,6-dioxo-3-(3,4,5trifluorobenzyl)-1,3,5-triazinan-1-yl\}acetate (8)

A mixture of $6(291 \mathrm{mg}, \leq 0.711 \mathrm{mmol})$ and 6-chloro-2-methyl- $2 H$-indazol-5-amine ${ }^{22}$ (129 $\mathrm{mg}, 0.711 \mathrm{mmol})$ in tert-amyl alcohol $(3 \mathrm{~mL})$ was stirred at $100{ }^{\circ} \mathrm{C}$ for $2 \mathrm{~h}$. The reaction mixture was cooled to room temperature, and then concentrated under reduced pressure. The residue was triturated with EtOAc and the solid was filtered, washed with EtOAc to afford 8 
(160 mg, 44\% over 2 steps) as a white solid. ${ }^{1} \mathrm{H}$ NMR (400 MHz, DMSO- $d_{6}, \mathrm{DCl}$ in $\left.\mathrm{D}_{2} \mathrm{O}\right) \delta$ $1.18(3 \mathrm{H}, \mathrm{t}, J=7.2 \mathrm{~Hz}), 4.12(2 \mathrm{H}, \mathrm{q}, J=7.2 \mathrm{~Hz}), 4.15(3 \mathrm{H}, \mathrm{s}), 4.47(2 \mathrm{H}, \mathrm{s}), 5.28(2 \mathrm{H}, \mathrm{s}), 7.37$ $(2 \mathrm{H}, \mathrm{dd}, J=8.8,7.0 \mathrm{~Hz}), 7.47(1 \mathrm{H}, \mathrm{s}), 7.74(1 \mathrm{H}, \mathrm{s}), 8.37(1 \mathrm{H}, \mathrm{s}) .{ }^{13} \mathrm{C} \mathrm{NMR}(100 \mathrm{MHz}$, DMSO- $d_{6}, \mathrm{DCl}$ in $\left.\mathrm{D}_{2} \mathrm{O}\right) \delta 14.04,40.20,42.78,44.44,61.25,79.33,111.93(\mathrm{dd}, J=16.1,5.1$ Hz), 116.84, 120.66, 125.43, 127.92, 128.65, 131.63, 133.46-133.65 (m), $137.98(\mathrm{dt}, J=$ $248.2,15.4 \mathrm{~Hz}), 146.39,150.22(\mathrm{ddd}, J=247.0,10.1,3.9 \mathrm{~Hz}), 150.39,150.52,168.00$. HRMS-ESI $(\mathrm{m} / \mathrm{z}):[\mathrm{M}+\mathrm{H}]^{+}$calcd for $\left[\mathrm{C}_{22} \mathrm{H}_{19} \mathrm{ClF}_{3} \mathrm{~N}_{6} \mathrm{O}_{4}\right]^{+}$523.1103; found 523.1104 .

(4E)-2-\{4-[(6-Chloro-2-methyl-2H-indazol-5-yl)imino]-2,6-dioxo-3-(3,4,5trifluorobenzyl)-1,3,5-triazinan-1-yl)-N-methylacetamide (2)

To a stirred solution of $8(445 \mathrm{mg}, 0.851 \mathrm{mmol})$ in THF/MeOH $(4.5 \mathrm{~mL}, \mathrm{v} / \mathrm{v}=1 / 1)$ was added aqueous $\mathrm{NaOH}(1 \mathrm{M}$ solution, $2.55 \mathrm{~mL}, 2.55 \mathrm{mmol}$ ) at room temperature. After stirring at room temperature for $70 \mathrm{~min}$, the reaction mixture was diluted with EtOAc and then quenched with aqueous $2 \mathrm{M} \mathrm{HCl}$ solution. The aqueous layer was extracted with EtOAc. The organic layer was washed with $\mathrm{H}_{2} \mathrm{O}$ and brine, dried over $\mathrm{Na}_{2} \mathrm{SO}_{4}$, and concentrated under reduced pressure. The residue was triturated with diisopropylether and the solid was filtered, washed with diisopropylether to afford a crude residue $(467 \mathrm{mg})$. The crude residue (100 mg, $\leq 0.202 \mathrm{mmol})$ in THF ( $2 \mathrm{~mL})$ were added methylamine (2M in THF, $0.152 \mathrm{~mL}, 0.303 \mathrm{mmol})$, $N, N$-diisopropylethylamine $(0.106 \mathrm{~mL}, 0.606 \mathrm{mmol})$, and HATU (115 mg, $0.303 \mathrm{mmol})$. After stirring at room temperature overnight, the reaction mixture was diluted with $\mathrm{H}_{2} \mathrm{O}$ and EtOAc. The aqueous layer was extracted with EtOAc. The organic layer was washed with 
$\mathrm{H}_{2} \mathrm{O}$ and brine, dried over $\mathrm{MgSO}_{4}$, and concentrated under reduced pressure. The residue was purified by silica gel column chromatography $\left(\mathrm{CHCl}_{3} / \mathrm{MeOH}\right.$, gradient, $\left.0-2 \% \mathrm{MeOH}\right)$. The collected fraction was recrystallized from $n$-hexane/EtOAc to afford 2 (26.6 mg, 29\% over 2 steps) as a white solid. ${ }^{1} \mathrm{H}$ NMR (400 MHz, DMSO- $d_{6}, \mathrm{DCl}$ in $\left.\mathrm{D}_{2} \mathrm{O}\right) \delta 2.57(3 \mathrm{H}, \mathrm{s}), 4.15(3 \mathrm{H}$, s), $4.27(2 \mathrm{H}, \mathrm{s}), 5.24(2 \mathrm{H}, \mathrm{s}), 7.38(1 \mathrm{H}, \mathrm{s}), 7.41(2 \mathrm{H}, \mathrm{dd}, J=8.7,7.2 \mathrm{~Hz}), 7.73(1 \mathrm{H}, \mathrm{s}), 8.36$ $(1 \mathrm{H}, \mathrm{s}) .{ }^{13} \mathrm{C}$ NMR $\left(100 \mathrm{MHz}, \mathrm{DMSO}-d_{6}, \mathrm{DCl}\right.$ in $\left.\mathrm{D}_{2} \mathrm{O}\right) \delta 25.47,40.19,43.99,44.47,79.37$, $111.98(\mathrm{dd}, J=16.9,5.1 \mathrm{~Hz}), 115.78,116.77,120.81,125.39,128.64,132.87,133.78-133.97$ (m), $137.91(\mathrm{dt}, J=248.0,15.4 \mathrm{~Hz}), 145.57,146.14,150.22(\mathrm{ddd}, J=246.7,9.9,4.0 \mathrm{~Hz})$, 150.30, 150.51, 166.97. HRMS-ESI (m/z): $[\mathrm{M}+\mathrm{H}]^{+}$calcd for $\left[\mathrm{C}_{21} \mathrm{H}_{18} \mathrm{ClF}_{3} \mathrm{~N}_{7} \mathrm{O}_{3}\right]^{+}$508.1106; found 508.1106 .

\section{3-(tert-Butyl)-6-(ethylthio)-1,3,5-triazine-2,4(1H,3H)-dione (9)}

Compound 9 was prepared according to the reported procedure. ${ }^{21}{ }^{1} \mathrm{H}$ NMR $(400 \mathrm{MHz}$, $\left.\mathrm{CDCl}_{3}\right) \delta 1.36(3 \mathrm{H}, \mathrm{t}, J=7.4 \mathrm{~Hz}), 1.66(9 \mathrm{H}, \mathrm{s}), 3.14(2 \mathrm{H}, \mathrm{q}, J=7.4 \mathrm{~Hz}) .{ }^{13} \mathrm{C}$ NMR $(100 \mathrm{MHz}$, $\left.\mathrm{CDCl}_{3}\right) \delta 14.35,25.22,29.20,61.55,152.26,154.19,165.96$. HRMS-ESI $(\mathrm{m} / \mathrm{z}):[\mathrm{M}+\mathrm{H}]^{+}$ calcd for $\left[\mathrm{C}_{9} \mathrm{H}_{16} \mathrm{~N}_{3} \mathrm{O}_{2} \mathrm{~S}\right]^{+}$230.0958; found 230.0952 .

3-(tert-Butyl)-6-(ethylthio)-1-(2,4,5-trifluorobenzyl)-1,3,5-triazine-2,4(1H,3H)-dione (10)

A mixture of $9(100 \mathrm{mg}, 0.436 \mathrm{mmol})$, potassium carbonate $(78.0 \mathrm{mg}, 0.567 \mathrm{mmol})$, and 1 (bromomethyl)-2,4,5-trifluorobenzene $(0.063 \mathrm{~mL}, 0.480 \mathrm{mmol})$ in $\mathrm{MeCN}(0.8 \mathrm{~mL})$ was 
stirred at $80{ }^{\circ} \mathrm{C}$ for $2 \mathrm{~h}$. The reaction mixture was cooled to room temperature, and then the mixture was diluted with EtOAc. The precipitate was filtered, and the filtrate was concentrated under reduced pressure. The residue was purified by silica gel column chromatography ( $n$-hexane/EtOAc gradient, $0-30 \%$ EtOAc) to afford $10(151 \mathrm{mg}, 93 \%)$ as a colorless oil. ${ }^{1} \mathrm{H}$ NMR (400 MHz, $\left.\mathrm{CDCl}_{3}\right) \delta 1.33(3 \mathrm{H}, \mathrm{t}, J=7.4 \mathrm{~Hz}), 1.65(9 \mathrm{H}, \mathrm{s}), 3.15(2 \mathrm{H}$, q, $J=7.4 \mathrm{~Hz}), 5.03(2 \mathrm{H}, \mathrm{s}), 6.91-7.01(2 \mathrm{H}, \mathrm{m}) .{ }^{13} \mathrm{C} \mathrm{NMR}\left(100 \mathrm{MHz}, \mathrm{CDCl}_{3}\right) \delta 13.73,26.88$, 28.88, $41.05(\mathrm{~d}, J=4.4 \mathrm{~Hz}), 61.59,105.92(\mathrm{dd}, J=27.5,20.9 \mathrm{~Hz}), 116.24(\mathrm{ddd}, J=20.5$, 5.1, $1.5 \mathrm{~Hz}), 118.65(\mathrm{td}, J=10.5,5.4 \mathrm{~Hz}), 147.03(\mathrm{ddd}, J=246.1,12.8,3.7 \mathrm{~Hz}), 149.72(\mathrm{ddd}$, $J=252.4,13.9,12.5 \mathrm{~Hz}), 150.36,152.98,155.24(\mathrm{ddd}, J=246.5,9.5,2.9 \mathrm{~Hz}), 166.69$. HRMS-ESI (m/z): $[\mathrm{M}+\mathrm{H}]^{+}$calcd for $\left[\mathrm{C}_{16} \mathrm{H}_{19} \mathrm{~F}_{3} \mathrm{~N}_{3} \mathrm{O}_{2} \mathrm{~S}\right]^{+}$374.1145; found 374.1142.

\section{6-(Ethylthio)-1-(2,4,5-trifluorobenzyl)-1,3,5-triazine-2,4(1H,3H)-dione (11)}

A mixture of $10(4.88 \mathrm{~g}, 13.08 \mathrm{mmol})$ in TFA $(9.8 \mathrm{~mL})$ was stirred at room temperature for $4 \mathrm{~h}$ then stood at the same temperature overnight. After concentration under reduced pressure, the residue was azeotroped with toluene and triturated with diisopropylether to afford $\mathbf{1 1}$ (4.01 g, 97\%) as a white solid. ${ }^{1} \mathrm{H}$ NMR $\left(400 \mathrm{MHz}, \mathrm{CDCl}_{3}\right) \delta 1.37(3 \mathrm{H}, \mathrm{t}, J=7.4 \mathrm{~Hz}), 3.23$ $(2 \mathrm{H}, \mathrm{q}, J=7.4 \mathrm{~Hz}), 5.15(2 \mathrm{H}, \mathrm{s}), 6.95-7.09(2 \mathrm{H}, \mathrm{m}), 8.23(1 \mathrm{H}, \mathrm{br} \mathrm{s}) .{ }^{13} \mathrm{C}$ NMR $(100 \mathrm{MHz}$, DMSO-d $) \delta 13.73,26.40,40.66(\mathrm{~d}, J=3.7 \mathrm{~Hz}), 106.13(\mathrm{dd}, J=28.2,21.6 \mathrm{~Hz}), 116.51(\mathrm{dd}$, $J=20.9,4.8 \mathrm{~Hz}), 119.52(\mathrm{dq}, J=16.1,3.2 \mathrm{~Hz}), 145.05-149.96,150.08,152.42,154.70(\mathrm{ddd}$, $J=244.5,10.1,2.4 \mathrm{~Hz}), 169.98$. HRMS-ESI $(\mathrm{m} / \mathrm{z}):[\mathrm{M}+\mathrm{H}]^{+}$calcd for $\left[\mathrm{C}_{12} \mathrm{H}_{11} \mathrm{FN}_{3} \mathrm{O}_{2} \mathrm{~S}\right]^{+}$ 318.0519; found 318.0516. 
6-(Ethylthio)-3-[(1-methyl-1H-1,2,4-triazol-3-yl)methyl]-1-(2,4,5-trifluorobenzyl)-1,3,5triazine-2,4(1H,3H)-dione (12)

A mixture of 11 (2.50 g, $7.88 \mathrm{mmol})$, 3-(chloromethyl)-1-methyl-1H-1,2,4-triazole hydrochloride (1.99 g, $11.8 \mathrm{mmol})$, and potassium carbonate $(3.27 \mathrm{~g}, 23.6 \mathrm{mmol})$ in DMF (23 mL) was stirred at $60{ }^{\circ} \mathrm{C}$ for $3.5 \mathrm{~h}$. The reaction mixture was allowed to cool to room temperature and diluted with aqueous $\mathrm{NH}_{4} \mathrm{Cl}$ solution. The precipitate was filtered and washed with $\mathrm{H}_{2} \mathrm{O}$. The solid was purified by silica gel column chromatography (nhexane/EtOAc gradient, 30-60\% EtOAc) to afford $12(1.47 \mathrm{~g}, 45 \%)$ as a white solid. ${ }^{1} \mathrm{H}$ NMR $\left(400 \mathrm{MHz}, \mathrm{CDCl}_{3}\right) \delta 1.34(3 \mathrm{H}, \mathrm{t}, J=7.4 \mathrm{~Hz}), 3.20(2 \mathrm{H}, \mathrm{q}, J=7.4 \mathrm{~Hz}), 3.84(3 \mathrm{H}, \mathrm{s}), 5.16(2 \mathrm{H}$, s), $5.23(2 \mathrm{H}, \mathrm{s}), 6.92-6.98(1 \mathrm{H}, \mathrm{m}), 7.10-7.17(1 \mathrm{H}, \mathrm{m}), 7.93(1 \mathrm{H}, \mathrm{s}) .{ }^{13} \mathrm{C} \mathrm{NMR}(100 \mathrm{MHz}$, $\left.\mathrm{CDCl}_{3}\right) \delta 13.55,27.31,36.13,39.92,41.11(\mathrm{~d}, J=3.7 \mathrm{~Hz}), 105.80(\mathrm{dd}, J=27.5,20.9 \mathrm{~Hz})$, $116.20(\mathrm{dd}, J=20.5,3.7 \mathrm{~Hz}), 118.11(\mathrm{td}, J=11.0,4.9 \mathrm{~Hz}), 144.33,145.87-151.14,150.57$, 151.68, $155.18(\mathrm{ddd}, J=246.5,9.5,2.9 \mathrm{~Hz}), 159.29,169.56 . \mathrm{HRMS}-E S I(\mathrm{~m} / \mathrm{z}):[\mathrm{M}+\mathrm{H}]^{+}$ calcd for $\left[\mathrm{C}_{16} \mathrm{H}_{16} \mathrm{~F}_{3} \mathrm{~N}_{6} \mathrm{O}_{2} \mathrm{~S}\right]^{+}$413.1002; found 413.0998.

(6E)-6-[(6-Chloro-2-methyl-2H-indazol-5-yl)imino]-3-[(1-methyl-1H-1,2,4-triazol-3yl)methyl]-1-(2,4,5-trifluorobenzyl)-1,3,5-triazinane-2,4-dione (3, S-217622)

To a solution of $12(300 \mathrm{mg}, 0.727 \mathrm{mmol})$ and 6-chloro-2-methyl-2H-indazol-5-amine (172 $\mathrm{mg}, 0.946 \mathrm{mmol})$ in THF (6 mL) was added LHMDS (1M in THF; $1.46 \mathrm{~mL}, 1.46 \mathrm{mmol})$ 
dropwisely at $0{ }^{\circ} \mathrm{C}$. The reaction mixture was stirred at $0{ }^{\circ} \mathrm{C}$ for $2.5 \mathrm{~h}$ and then at $\mathrm{rt}$ for 40 min. The reaction was quenched with aqueous $\mathrm{NH}_{4} \mathrm{Cl}$ solution, and the aqueous layer was extracted with EtOAc. The organic layer was washed with brine, dried over $\mathrm{MgSO}_{4}$, and concentrated under reduced pressure. The residue was purified by silica gel column chromatography $\left(\mathrm{CHCl}_{3} / \mathrm{MeOH}\right.$ gradient, $\left.0-20 \% \mathrm{MeOH}\right)$. The solid was recrystallized from acetone $/ \mathrm{H}_{2} \mathrm{O}$ to afford 3 (S-217622) $(95.3 \mathrm{mg}, 25 \%)$ as a pale brown solid. ${ }^{1} \mathrm{H}$ NMR (400 MHz, DMSO- $d_{6}, \mathrm{DCl}$ in $\left.\mathrm{D}_{2} \mathrm{O}\right) \delta 3.90(3 \mathrm{H}, \mathrm{s}), 4.15(3 \mathrm{H}, \mathrm{s}), 5.04(2 \mathrm{H}, \mathrm{s}), 5.26(2 \mathrm{H}, \mathrm{s}), 7.44$ $(1 \mathrm{H}, \mathrm{m}), 7.52-7.65(2 \mathrm{H}, \mathrm{m}), 7.73(1 \mathrm{H}, \mathrm{s}), 8.40(1 \mathrm{H}, \mathrm{s}), 9.31(1 \mathrm{H}, \mathrm{s}) .{ }^{13} \mathrm{C} \mathrm{NMR}(100 \mathrm{MHz}$ DMSO- $d_{6}, \mathrm{DCl}$ in $\left.\mathrm{D}_{2} \mathrm{O}\right) \delta 37.34,38.04,40.06,40.29,106.16(\mathrm{dd}, J=28.2,21.6 \mathrm{~Hz}), 116.46-$ $116.70,116.70,120.54-120.76,120.76,125.93,129.10,132.35,143.84,145.98,146.38$ (ddd, $J=241.4,12.5,3.7 \mathrm{~Hz}), 146.60,148.52(\mathrm{td}, J=247.7,13.6 \mathrm{~Hz}), 150.43,150.50,155.22(\mathrm{ddd}$, $J=244.3,10.3,2.2 \mathrm{~Hz}), 155.58$. HRMS-ESI $(\mathrm{m} / \mathrm{z}):[\mathrm{M}+\mathrm{H}]^{+}$calcd for $\left[\mathrm{C}_{22} \mathrm{H}_{18} \mathrm{~F}_{3} \mathrm{ClN}_{9} \mathrm{O}_{2}\right]^{+}$ 532.1219; found 532.1221.

\section{Preparation of Compound 3 (S-217622) fumaric acid co-crystal.}

A mixture of 3 (S-217622) (1.17 g, $2.2 \mathrm{mmol})$ and fumaric acid (278 mg, $2.4 \mathrm{mmol})$ in EtOAc $(5.9 \mathrm{~mL})$ was stirred at room temperature for $45 \mathrm{~min}$. The suspension was filtrated to afford 3 (S-217622) fumaric acid co-crystal (1.37 g, $95 \%$ ) as a white solid. ${ }^{1} \mathrm{H}$ NMR (400 MHz, pyridine- $\left.d_{5}\right) \delta 3.64(\mathrm{~s}, 3 \mathrm{H}), 3.99(\mathrm{~s}, 3 \mathrm{H}), 5.56(\mathrm{~s}, 2 \mathrm{H}), 5.61(\mathrm{~s}, 2 \mathrm{H}), 7.16-7.25(\mathrm{~m}, 2 \mathrm{H}), 7.44$ (s, 2H), $7.81(\mathrm{~s}, 1 \mathrm{H}), 7.89(\mathrm{~s}, 1 \mathrm{H}), 7.89-7.97(\mathrm{~m}, 1 \mathrm{H}), 8.32(\mathrm{~s}, 1 \mathrm{H})$. 
Cells and viruses. Remdesivir was purchased from MedChemExpress. VeroE6/TMPRSS2 cells from the National Institutes of Biomedical Innovation (Tokyo, Japan) were used to evaluate the antiviral activity against SARS-CoV-2. Those prepared by Hokkaido University as previously reported ${ }^{23}$ were used to evaluate the antiviral activities against SARS-CoV and MERS-CoV. MRC-5 cells (CCL-171) were purchased from American Type Culture Collection (ATCC; Manassas, VA, USA). Cells were maintained in Dulbecco's modified Eagle's medium (Thermo Fisher Scientific) supplemented with 10\% heat-inactivated fetal bovine serum (FBS) (Sigma-Aldrich Co., Ltd.) at $37^{\circ} \mathrm{C}$ with $5 \% \mathrm{CO}_{2}$.

SARS-CoV-2 clinical isolates were obtained from the National Institute of Infectious Diseases (NIID; Tokyo, Japan): hCoV-19/Japan/TY/WK-521/2020 (Pango Lineage: A), hCoV-19/Japan/QK002/2020 (Alpha， B.1.1.7)， hCoV-19/Japan/QHN001/2020 (Alpha, B.1.1.7), hCoV-19/Japan/QHN002/2020 (Alpha, B.1.1.7), hCoV-19/Japan/TY7-501/2021 (Gamma, P.1), hCoV-19/Japan/TY7-503/2021 (Gamma, P.1), hCoV-19/Japan/TY8-612/2021 (Beta, B.1.351), hCoV-19/Japan/TY11-927-P1/2021 (Delta, B.1.617.2), and hCoV19/Japan/TY38-873/2021 (Omicron, B.1.1.529). All SARS-CoV-2 strains were propagated in VeroE6/TMPRSS2 cells, and infectious titers were determined by standard tissue culture infectious dose (TCID) 50 in VeroE6/TMPRSS2 cells. SARS-CoV (Hanoi strain) was provided by Dr. Koichi Morita of Nagasaki University ${ }^{24}$. MERS-CoV (EMC/2012) was provided by Dr. Bart L Haagmans, Erasmus University Medical Center ${ }^{25}$. VeroE6 cells (ATCC) were used to propagate SARS-CoV; VeroE6/TMPRSS2 cells were used to propagate MERS-CoV. HCoV-OC43 and HCoV-229E were obtained from ATCC. 
3CL protease inhibition assay. The 3CL protease inhibition assay was conducted in 384well plates (Corning 3702). The substance solution (10 mM dimethyl sulfoxide [DMSO] solution) was diluted to $250 \mu \mathrm{mol} / \mathrm{L}$ stepwise with a 3-fold dilution with DMSO. Finally, the solutions were mixed with $20 \mathrm{mmol} / \mathrm{L}$ Tris- $\mathrm{HCl}(\mathrm{pH} 7.5)$ as a compound solution. Ten microliters of compound solution was added manually to each well, then $5 \mu \mathrm{L}$ of $16 \mu \mathrm{M}$ substrate in inhibition buffer (2 mM EDTA, $20 \mathrm{mM}$ DTT, 0.02\% BSA, and $20 \mathrm{mM}$ Tris-HCl, $\mathrm{pH}$ 7.5) was added. The reaction was initiated by adding $5 \mu \mathrm{L}$ of $12 \mathrm{nM} 3 \mathrm{CL}$ protease in inhibition buffer and incubated at room temperature for $3 \mathrm{~h}$. The following operations were the same as those described in the biological screening.

Biological Screening. The compound screening assay was performed in 384-well plates (Corning 3702 or Greiner 781280). One-hundred fifty nanoliters of testing compound at various concentrations was added to each well by an ECHO 555 dispenser (LABCYTE INC.). Next, $7.5 \mu \mathrm{L}$ of $8 \mu \mathrm{M}$ substrate (Dabcyl-KTSAVLQSGFRKME [Edans] -NH2, 3249-v, PEPTIDE INSTITUTE, Inc.) in assay buffer $(100 \mathrm{mM} \quad \mathrm{NaCl}, \quad 1 \mathrm{mM}$ ethylenediaminetetraacetic acid [EDTA], $10 \mathrm{mM}$ DL-dithiothreitol (DTT), 0.01\% bovine serum albumin [BSA], and $20 \mathrm{mM}$ Tris- $\mathrm{HCl}, \mathrm{pH} 7.5$ ) was dispensed using Multidrop Combi (Thermo Scientific). The reaction was initiated by adding $7.5 \mu \mathrm{L}$ of 6 or $0.6 \mathrm{nM} 3 \mathrm{CL}$ protease in assay buffer and incubated at room temperature for $3 \mathrm{~h}$. After incubation, the reaction was stopped by adding $45 \mu \mathrm{L}$ of water solution containing $0.1 \%$ formic acid, $10 \%$ acetonitrile, and $0.05 \mu \mathrm{mol} / \mathrm{L}$ Internal Standard (IS) peptide (Dabcyl-KTSAVLeu $\left[{ }^{13} \mathrm{C}_{6},{ }^{15} \mathrm{~N}\right]-\mathrm{Q}$, custom 
synthesized by PEPTIDE INSTITUTE, Inc.). The reactions were analyzed with MS using a RapidFire 360 high-throughput sampling robot (Agilent Technologies) connected to an iFunnel Agilent 6550 accurate mass quadrupole time-of-flight mass spectrometer using electrospray. Peak areas were acquired and analyzed using a RapidFire Integrator (Agilent Technologies). Reaction product peak areas were acquired from $\mathrm{m} / \mathrm{z} 499.27$; IS peak areas were acquired from $\mathrm{m} / \mathrm{z} 502.78$. $\mathrm{IC}_{50}$ values were determined by plotting compound concentration vs inhibition and fitting data with a 4-parameter logistical fit (Model 205, XLfit).

Cellular Antiviral Activity. Antiviral activity against SARS-CoV-2, SARS-CoV, MERS$\mathrm{CoV}$ and $\mathrm{HCoV}-229 \mathrm{E}$ was assessed by monitoring cell viability; that against $\mathrm{HCoV}-\mathrm{OC} 43$ was assessed by monitoring viral RNA in a cell suspension. $\mathrm{EC}_{50}$ values were determined by plotting compound concentration vs inhibition and fitting data with a 4-parameter logistical fit (Model 205, XLfit). EC 90 values against $\mathrm{HCoV-OC43}$ were determined from the resulting dose-response curves and calculated with the two-point method.

Antiviral activities against SARS-CoV-2 were evaluated using VeroE6/TMPRSS2 cells. VeroE6/TMPRSS2 cells $\left(1.5 \times 10^{4} /\right.$ well $)$ suspended in minimum essential medium (MEM) (Thermo Fisher Scientific) supplemented with heat-inactivated 2\% FBS were seeded into 96well plates with diluted compounds in each well. Cells were infected with each SARS-CoV2 at $30-3000 \mathrm{TCID}_{50} /$ well and cultured at $37^{\circ} \mathrm{C}$ with $5 \% \mathrm{CO}_{2}$ for 3 days or 4 days. Cell viability was assessed using a CellTiter-Glo® 2.0 assay (Promega). The $\mathrm{CC}_{50}$ was assessed in the absence of viruses after being cultured for 3 days. 
Antiviral activities against SARS-CoV and MERS-CoV were evaluated at Hokkaido University using VeroE6/TMPRSS2 cells as previously reported ${ }^{23}$. VeroE6/TMPRSS2 cells $\left(1.5 \times 10^{4} /\right.$ well $)$ suspended in 2\% FBS-containing MEM were seeded into 96-well plates with diluted compounds in each well. Cells were infected with each SARS-CoV at 1000 TCID $50 /$ well or MERS-CoV $2500 \mathrm{TCID}_{50} /$ well and cultured at $37^{\circ} \mathrm{C}$ with $5 \% \mathrm{CO}_{2}$ for 3 days. Cell viability was assessed via (3-[4,5-dimethyl-2-thiazolyl]-2,5-diphenyl-2 $H$-tetrazolium bromide (MTT) assay (Nacalai Tesque) as previously described ${ }^{26}$.

Antiviral activity against HCoV-229E was evaluated using MRC-5 cells. MRC-5 cells (2.0 $\times 10^{4} /$ well) suspended in 2\% FBS-containing MEM were seeded into 96-well plates and incubated at $37{ }^{\circ} \mathrm{C}$ with $5 \% \mathrm{CO}_{2}$ overnight. The next day, the cells were infected with $\mathrm{HCoV}$ 229E at $1000 \mathrm{TCID}_{50} /$ well and incubated at $37{ }^{\circ} \mathrm{C}$ with $5 \% \mathrm{CO}_{2}$ for $1 \mathrm{~h}$, followed by removal of the inoculum and added 2\% FBS-containing MEM with the diluted compounds. Cells infected with $\mathrm{HCoV}-229 \mathrm{E}$ were incubated at $37{ }^{\circ} \mathrm{C}$ with $5 \% \mathrm{CO}_{2}$ for 3 days. Cell viability was assessed using a CellTiter-Glo® 2.0 assay.

Antiviral activity against $\mathrm{HCoV}-\mathrm{OC} 43$ was evaluated using MRC-5 cells. MRC-5 cells (2.0 $\times 10^{4} /$ well) suspended in 2\% FBS-containing MEM were seeded into 96-well plates and incubated at $37{ }^{\circ} \mathrm{C}$ with $5 \% \mathrm{CO}_{2}$ overnight. The next day, the cells were infected with $\mathrm{HCoV}$ OC43 at $100 \mathrm{TCID}_{50} /$ well and incubated at $37^{\circ} \mathrm{C}$ with $5 \% \mathrm{CO}_{2}$ for $1 \mathrm{~h}$, followed by removal of the inoculum and added 2\% FBS-containing MEM with the diluted compounds. Cells infected with $\mathrm{HCoV}-\mathrm{OC} 43$ were incubated at $37^{\circ} \mathrm{C}$ with $5 \% \mathrm{CO}_{2}$ for $42 \mathrm{~h}$, and viral RNA was extracted from the supernatants using a Quick-RNA Viral Kit (ZYMO RESEARCH, \# R1041). Viral RNA was quantified via real-time PCR (Applied Biosystems, QuantStudio 3) 
with specific primers and probes for $\mathrm{HCoV}-\mathrm{OC} 43$ detection $^{27}$.

Cellular antiviral activity in the presence of mouse serum. Antiviral activity against SARS-CoV-2 in the presence of mouse serum was assessed by monitoring cell viability. S217622 (fumaric acid co-crystal) was diluted with $3.125 \%, 6.25 \%, 12.5 \%$, and $25 \%$ mouse serum in MEM supplemented with heat-inactivated 2\% FBS. One hundred microliters of serially diluted compound solutions were added to a 96-well plate and incubated at room temperature for approximately $1 \mathrm{~h}$. Each $50 \mu \mathrm{L} /$ well of VeroE6/TMPRSS2 cells was adjusted to $3.0 \times 10^{5}$ cells $/ \mathrm{mL}$ with MEM supplemented with heat-inactivated 2\% FBS and dispensed on the plate. Each $50 \mu \mathrm{L} /$ well of SARS-CoV-2 was added at $10000 \mathrm{TCID}_{50} /$ well and cultured at $37{ }^{\circ} \mathrm{C}$ with $5 \% \mathrm{CO}_{2}$ for 3 days. Cell viability was assessed using a CellTiter-Glo ${ }^{\circledR} 2.0$ assay, followed by determination of the $\mathrm{EC}_{50}$ value from the cell viability. $\mathrm{PA}-\mathrm{EC}_{50}$ extrapolated to $100 \%$ serum was calculated by linear regression using the $\mathrm{EC}_{50}$ value of each serum concentration. PS extrapolated to $100 \%$ serum was calculated by dividing the PA-EC 50 (extrapolated value of $100 \%$ mouse serum) by $\mathrm{EC}_{50}$ (in the presence of mouse serum).

Human protease enzyme assay. Selectivity tests against varieties of host protease activity were conducted by Eurofins Panlabs Discovery Services Taiwan, Ltd. on behalf of SHIONOGI Co. \& Ltd. as per established protocols. S-217622 (fumaric acid co-crystal) was tested on a set of seven proteases (caspase-2, chymotrypsin, cathepsin $\mathrm{B} / \mathrm{D} / \mathrm{G} / \mathrm{L}$ and thrombin) at $100 \mu \mathrm{M}$. 
In vivo SARS-CoV-2 infection and treatment studies. In vivo SARS-CoV-2 infection experiments were conducted in accordance with the guidelines of the Association for Assessment and Accreditation of Laboratory Animal Care (AAALAC). The animal study protocol was approved by the director of the institute based on the report of the Institutional Animal Care and Use Committee of Shionogi Research Laboratories.

Mouse in vivo SARS-CoV-2 infection studies were done at Shionogi Pharmaceutical Research Center (Osaka, Japan). Five-week-old female BALB/cAJcl mice (CLEA Japan, Inc.; $\mathrm{n}=5$ or 10 per group) were intranasally inoculated with SARS-CoV-2 Gamma strain (hCoV-19/Japan/TY7-501/2021) (10000 TCID $50 /$ mouse) under anesthesia. Immediately after infection, the mice were orally administered S-217622 (fumaric acid co-crystal) $(2,8,16$ or $32 \mathrm{mg} / \mathrm{kg}$ q12h; $\mathrm{n}=5$ per group $)$ or vehicle $(0.5 \mathrm{w} / \mathrm{v} \%$ methyl cellulose in aqueous solution $\mathrm{q} 12 \mathrm{~h} ; \mathrm{n}=10$ per group), for 1 day. Twenty-four hours postinfection, the mice were euthanized via cervical dislocation under anesthesia; their lungs were removed and the viral titers in the lung homogenates were determined using VeroE6/TMPRSS2 cells. Viral titers are expressed as $\log _{10} \mathrm{TCID}_{50} / \mathrm{mL}$.

PK study in infected mice. PK experiments in infected mice were conducted in accordance with the guidelines provided by AAALAC and were approved by IACUC of Shionogi Research Laboratories.

Mouse PK studies were done at Shionogi Pharmaceutical Research Center (Osaka, Japan). BALB/cAJcl mice were intranasally inoculated with SARS-CoV-2 Gamma strain (hCoV19/Japan/TY7-501/2021) (10000 TCID $_{50} /$ mouse) and orally administered with S-217622 
(fumaric acid co-crystal) $(2,8,16$, or $32 \mathrm{mg} / \mathrm{kg})$ immediately after infection. Blood was taken at $0.5,1,2,4,6,12,18$ and $24 \mathrm{~h}$ after dosing $(\mathrm{n}=4$ per group per timepoint) and plasma concentrations of S-217622 were determined by LC/MS/MS. LC/MS/MS analysis was performed using Vanquish Binary Flex system equipped with TSQ Altis (Thermo Fisher Scientific). The PK parameters of the plasma concentrations of S-217622 were calculated using Phoenix WinNonlin (Ver. 8.1, Certara, L.P.). The plasma concentrations of all dosing groups in the in vivo SARS-CoV-2 infection and treatment studies were simulated by nonparametric analysis from plasma concentration data obtained in the PK study. The following PK parameters were calculated based on the non-compartmental method.

Metabolic stability studies. Rat liver microsomes (pool of 5, male) were purchased from the Jackson Laboratory Japan, Inc. (Yokohama, Japan) or Charles River Japan, Inc. (Yokohama, Japan). Human liver microsomes (HLM, pool of 15, male and female) were purchased from Sekisui XenoTech (Kansas City, KS). Metabolic stabilities of the test compounds in rat and human liver microsomes were determined at $0.5 \mu \mathrm{M}$. The compounds were incubated with $0.5 \mathrm{mg}$ protein $/ \mathrm{mL}$ in suspension in buffer $(50 \mathrm{mM}$ Tris- $\mathrm{HCl}$ buffer, $\mathrm{pH}$ 7.4, $150 \mathrm{mM} \mathrm{KCl}, 10 \mathrm{mM} \mathrm{MgCl} 2,1 \mathrm{mM} \mathrm{NADPH})$ at $37^{\circ} \mathrm{C}$. Microsomal incubations were initiated by adding 100-fold concentrated solution of the compounds. Incubations were terminated by adding a 2 -fold volume of organic solvent $(\mathrm{MeCN} / \mathrm{MeOH}=1: 1)$ after 0 and 30 min of incubation at $37^{\circ} \mathrm{C}$. The precipitation protein was removed by centrifugation. The supernatants were analyzed by liquid chromatography tandem mass spectrometry (LC/MS/MS). LC/MS/MS was performed using LCMS-8060 (SHIMADZU 
CORPORATION, Kyoto). All incubations were conducted in duplicate, and the percentage of compound remaining at the end of the incubation was determined from the LC/MS/MS peak area ratio.

Rat PK studies. The animal study protocol was approved by the director of the institute after reviewing the protocol by the Institutional Animal Care and Use Committee in terms of the 3R (Replacement/Reduction/Refinement) principles.

Rat PK studies were done at Shionogi Pharmaceutical Research Center (Osaka, Japan). Eight-week-old male Sprague-Dawley rats were purchased from Charles River Laboratories. For oral administration, the dosing vehicle was dimethyl sulfoxide $/ 0.5 \%$ methylcellulose $(400 \mathrm{cP})=1: 4$. The compound was orally administered at $1-2 \mu \mathrm{mol} / 5 \mathrm{~mL} / \mathrm{kg}(\mathrm{n}=2)$ under non-fasted conditions. Blood samples $(0.2 \mathrm{~mL})$ were collected with $1 \mathrm{~mL}$ syringes containing anticoagulants (EDTA-2K and heparin) at 0.5, 1, 2, 4, 8, and $24 \mathrm{~h}$ after dosing. For intravenous administration, compounds were formulated as solutions in dimethyl sulfoxide/propylene glycol $(1: 1, \mathrm{v} / \mathrm{v})$ and intravenously administered via the tail vein at $0.5-$ $1.0 \mu \mathrm{mol} / \mathrm{mL} / \mathrm{kg}(\mathrm{n}=2)$ under isoflurane anesthesia under non-fasted conditions. Blood samples $(0.2 \mathrm{~mL})$ were collected with $1-\mathrm{mL}$ syringes containing anticoagulants (EDTA-2 $\mathrm{K}$ and heparin) at 3, 10, 30, 60, 120, 240 and $360 \mathrm{~min}$ after dosing. Blood samples were centrifuged to obtain plasma samples, which were transferred to each tube and stored in a freezer until analysis. Plasma concentrations were determined by LC/MS/MS following protein precipitation with $\mathrm{MeOH}$ or $\mathrm{MeCN}$. LC/MS/MS analysis was performed using a SCIEX Triple Quad 5500 or SCIEX API5000 or SCIEX Triple Quad 5500 (Sciex, 
Framingham, MA). PK parameters were calculated via non-compartmental analysis.

Dog/Monkey PK studies. PK experiments in dogs and monkeys were conducted in accordance with the guidelines provided by AAALAC. The animal study protocol was approved by the director of the institute after reviewing the protocol by the Institutional Animal Care and Use Committee in terms of the 3R (Replacement/Reduction/Refinement) principles.

Dog PK studies were done at Shionogi Pharmaceutical Research Center (Osaka, Japan), and Monkey PK studies were done at Shionogi Aburahi Research Center (Shiga, Japan). Male beagles were purchased from Marshall BioResources. Female cynomolgus monkeys were purchased from Shin Nippon Biomedical Laboratories, Ltd. or HAMRI CO., Ltd. For oral administration, dosing vehicles were $0.5 \%$ methylcellulose $(400 \mathrm{cP})$. The compound was orally administered at $3 \mathrm{mg} / 2 \mathrm{~mL} / \mathrm{kg}(\mathrm{n}=3)$ under non-fasted conditions. Blood samples $(0.3$ $\mathrm{mL}$ ) were collected with 1-mL syringes containing anticoagulants (EDTA-2K and heparin) at $0.25,0.5,1,2,4,8$ and $24 \mathrm{~h}$ after dosing. For intravenous administration, compounds were formulated as solutions in dimethyl acetamide/ethanol/20\% HP- $\beta-\mathrm{CD}$ in carbonate buffer (pH 9.0) (2:3:5, by vol.) and intravenously administered via forelimb or hindlimb vein at 0.1 $\mathrm{mg} / 0.2 \mathrm{~mL} / \mathrm{kg}(\mathrm{n}=2)$ under non-fasted conditions. Blood samples $(0.2 \mathrm{~mL})$ were collected with 1-mL syringes containing anticoagulants (EDTA-2 $\mathrm{K}$ and heparin) at 2, 5, 15, 30, 60, 120, 240, 480 and 1440 min after dosing. Blood samples were centrifuged to obtain plasma samples, which were transferred to each tube and stored in a freezer until analysis. Plasma concentrations were determined by LC/MS/MS following protein precipitation with $\mathrm{MeOH}$ 
or MeCN. LC/MS/MS analysis was performed using a SCIEX API5000 or SCIEX Triple Quad 6500 or Triple Quad ${ }^{\mathrm{TM}} 6500+$ (Sciex, Framingham, MA). PK parameters were calculated by non-compartmental analysis.

Virtual screening. As a target structure for virtual screening, we retrieved the crystal structure of the SARS-CoV-2 3CL ${ }^{\text {pro }}$ in complex with a non-covalent inhibitor, X77 (PDBID: 6W63) ${ }^{19}$, from PDB. First, the structure was prepared using Protein Preparation Wizard ${ }^{28}$. Missing atoms and side chains were added, and the ionization states of the amino acids were calculated using Epic ${ }^{29,30}$. Hydrogen bond networks were optimized, and energy was minimized with a heavy atom restraint of $0.3 \AA$. All water molecules were removed from the crystal structure, and the docking grid was set to the center of the bound ligand of X77. An in-house compound library was preprocessed by Ligprep ${ }^{31}$ before docking. Virtual screening was performed via Glide ${ }^{32,33}$ in SP mode. The generated docking poses were filtered by the predefined pharmacophores using Phase ${ }^{34,35}$. The pharmacophores were set as the acceptor sites with the sidechain NH donor of His163 in the S1 pocket, the lipophilic site in the S2 pocket and the acceptor site with the Glu166 main-chain NH. Finally, the 300 top-scoring compounds that matched all pharmacophores were selected for enzymatic assays. These procedures were conducted using Schrödinger Drug Discovery Suite 2019-4.

\section{Expression and purification of SARS-CoV-2 $3 C^{\text {pro }}$ protein. The SARS-CoV-2 $3 C^{\text {pro }}$} (1-306) containing an $\mathrm{N}$-terminal 10-histidine tag followed by a thrombin cleavage site and the SARS-CoV-2 $3 \mathrm{CL}^{\text {pro }}$ (1-306) containing a thrombin cleavage site followed by a C- 
terminal 10-histidine tag were cloned into pET15b vectors. Two $3 \mathrm{CL}^{\text {pro }}$ constructs were expressed and purified in the same manner as below. E. coli strain BL21 Star (DE3) (Thermo Fisher Scientific) was transformed by the expression plasmid, and then precultivated in LB medium containing $100 \mathrm{mg} / \mathrm{mL}$ of ampicillin sodium salt. Six milliliters of preculture was inoculated into $600 \mathrm{~mL}$ of fresh TB medium supplemented by $100 \mathrm{mg} / \mathrm{mL}$ of ampicillin sodium salt in a $2-\mathrm{L}$ flask with baffles. After vigorous shaking at $37^{\circ} \mathrm{C}, 1 \mathrm{mM}$ IPTG was added for the induction when the optical density (OD) 600 reached 1.0. After induction for 16 $\mathrm{h}$ at $16^{\circ} \mathrm{C}$, the cells were harvested by centrifugation.

Cells expressing SARS-CoV-2 3CL ${ }^{\text {pro }}$ were resuspended and sonicated. The clarified lysate was subjected to HisTrap FF $5 \mathrm{~mL}$ (Cytiva) equilibrated with $20 \mathrm{mM}$ Tris- $\mathrm{HCl}$ (pH 8.0), 300 $\mathrm{mM} \mathrm{NaCl}, 1 \mathrm{mM}$ DTT, and $20 \mathrm{mM}$ imidazole, and the proteins were eluted with a linear concentration gradient of imidazole $(20-500 \mathrm{mM})$. Fractions containing SARS-CoV-2 $3 \mathrm{CL}^{\text {pro }}$ were collected and mixed with thrombin His-tag at $4{ }^{\circ} \mathrm{C}$ overnight to remove the $\mathrm{N}$ or C-terminus. Thrombin-treated SARS-CoV-2 3CL pro was applied to HisTrap FF $5 \mathrm{~mL}$ (Cytiva) to remove proteins with uncleaved His-tags. The flow-through fraction was applied to a Superdex 200 16/60 (Cytiva) equilibrated with 20 mM HEPES (pH 7.5), $150 \mathrm{mM} \mathrm{NaCl}$, and $1 \mathrm{mM} \mathrm{DTT}$, and the fraction containing the major peak was collected.

\section{Co-crystallization of SARS-CoV-2 3CL ${ }^{\text {pro }}$ with compound 1 and 3 (S-217622),} diffraction data collection, and structure determination. C-terminal His-tag free SARSCoV-2 3CL ${ }^{\text {pro }}$ protein $(4.4 \mathrm{mg} / \mathrm{mL})$ was incubated with $500 \mathrm{mM}$ compound 1 for $1 \mathrm{~h}$ at room temperature, and the complexes were crystallized by sitting-drop vapor diffusion at $20^{\circ} \mathrm{C}$. 
The crystal of the compound $\mathbf{1}$ complex was grown with buffer containing $0.2 \mathrm{M}$ ammonium citrate tribasic, $\mathrm{pH} 7.0$, with $20 \%$ (w/v) PEG 3350.

N-terminal His-tag-free SARS-CoV-2 3CL pro protein $(4.6 \mathrm{mg} / \mathrm{mL})$ was incubated with 500 $\mathrm{mM}$ of S-217622 for $1 \mathrm{~h}$ at room temperature, and the complexes were crystallized by sittingdrop vapor diffusion at $20^{\circ} \mathrm{C}$. The S-217622 complex crystal was grown with buffer containing $0.1 \mathrm{M}$ BIS-Tris, pH 6.5 , with $2.0 \mathrm{M}$ ammonium sulfate.

X-ray diffraction data were collected using a Rigaku HyPix6000C detector mounted on a Rigaku FR-X rotating anode generator. Data were processed by CrysAlis Pro $^{36}$. The structures were determined by molecular replacement using MOLREP ${ }^{37}$ with the SARS-

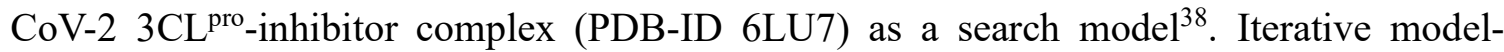
building cycles were performed with $\mathrm{COOT}^{37}$ and refined using $\mathrm{REFMAC}^{39}$. The data collection and structure refinement statistics were summarized in Table S5.

\section{Supporting Information}

- $\quad{ }^{1} \mathrm{H}-\mathrm{NMR}$ and ${ }^{13} \mathrm{C}-\mathrm{NMR}$ spectra of synthetic compounds, HPLC traces of compounds 13, and S-217622 (3) fumaric acid co-crystal. Experimental Procedures for in vitro safety, supporting tables (Tables S1-S3) for the in vitro antiviral activities of S-217622 (3), and tables for the in vitro safety experiments (Table S4) and crystallography data collection and refinement statistics (Table S5).

\section{Accession Code}

The coordinates and structural factors of SARS-CoV-2 3CL pro in complex with 1 and 3 (S- 
217622) have been deposited into PDB with accession numbers 7VTH and 7VU6, respectively. Authors will release the atomic coordinates and experimental data upon article publication.

\section{Author contributions}

Y.U., S.U., and K.N. contributed equally to this paper.

Conceptualization: T.K., Y.T.; Methodology: S.Y., H.N., Y.Y., S.T.; Formal Analysis: S.U.,

K.N.;H.N.,Y.Y., S.Y., S.K., T.M., T.K., Y.T.; Investigation: Y.U., S.U., K.N., H.N., Y.Y., S.Y., Y.M., Y.T., K.K., T.S., K.K., A.N., S.K., T.S., S.T., K.U., S.A., A.S.; Resources: M.S., Y.O., H.S.; Writing - Original Draft Preparation: Y.U., S.U., K.N., H.N., Y.T.; Writing - Review \& Editing: Y.U., S.U., K.N., H.N., T.S., M.S., Y.O., H.S., T.S., T.K., Y.T.; Visualization: Y.U., S.U., H.N., Y.M., S.K., Y.T.; Project Administration: Y.U., S.U., K.N., J.N., Y.Y., S.Y., Y.M., T.M., S.A.,.T.S., T.K., Y.T.; Supervision: T.K., Y.T.

\section{Notes}

SHIONOGI has applied for a patent covering 1, 2, and 3 (S-217622). Y.U., S.U., K.N., H.N., Y.Y., S.Y., Y.M., Y.T., K.K., T.S., K.K., A.N., S.K., T.S., S.T., K.U., T.M., S.A., A.S., T.S., T.K., and Y.T. are employees of SHIONOGI \& Co., Ltd. S.U., K.N., H.N., Y.M., Y.T., K.K., T.S., K.K., S.K., TS, S.T., K.U., T.S., and T.K. are shareholders in SHIONOGI \& Co., Ltd. M.S., Y.O., and H.S. are financially supported by the joint research fund from SHIONOGI \& 
Co., Ltd.

\section{Acknowledgments}

We thank all participants and investigator teams in the clinical study. We acknowledge the National Institute of Infectious Diseases (NIID), Dr. Kouichi Morita (Nagasaki University) and Dr. Bart Haagmans (Erasmus University Medical Center) for providing the SARS-CoV2 strains, SARS-CoV, and MERS-CoV, respectively. We are also grateful to all our colleagues who participated in the COVID-19 antiviral program at SHIONOGI: Yasushi Hasegawa, Masahiro Masuda, Rina Yasui, Misato Kitamura, Keisuke Mizote, Kotaro Nagatani, Shomitsu Maeno, Tatsuya Tanaka, Azusa Okano, Akinari Sumita, Masayuki Takamatsu, Manabu Kato, Hiroyuki Meichin, Yu Takahashi, Shinya Hisakawa, Yoshihide Sugata, Takao Oyama, Shinichiro Hara, Atsuhiro Iimuro, and Eiichi Kojima, for the compound synthesis; Tetsuya Miyano for the physicochemical studies; Masayoshi Ogawa for structural analysis of the compounds; Akira Kugimiya, Akira Ino, and Kenji Yamawaki for scientific discussion and advice; Takao Shishido, Keita Fukao, Takayuki Kuroda, Masaaki Nakashima, Ryuichi Yano, Yoko Kajiwara, Keiichi Taniguchi, Masaaki Izawa, Shinji Kusakabe, Sachi Takahara, Keiko Baba, and Shigeru Miki for the pharmacological studies; Junji Yamane for X-ray crystallography analysis; Shinpei Yoshida, Yukari Tanaka, Ryoko Oka, and all members of Drug Metabolism \& Pharmacokinetics 1\&2 group for the DMPK studies; and Yoko Nishimura, Keigo Matsuyama, Sho Hasegawa, Chinami Nekomoto, and Kayoko Kanasaki for the safety studies. We also thank Shionogi Technoadvance Research Co., Ltd. for the compound supplies and technical support in the pharmacological studies. We thank Traci 
Raley, MS, ELS, from Edanz (https://jp.edanz.com/ac) for editing a draft of this manuscript.

\author{
Abbreviations \\ CDI, $N, N$ '-carbonyldiimidazole; DBU, 1,8-diazabicyclo[5.4.0]-7-undecene; DMA, $N, N$ - \\ dimethylacetamide; DMEM, dulbecco's modified eagle medium; DMSO, dimethyl \\ sulfoxide; DTT, 1,4-dithiothreitol; ESI, electrospray ionization; EtOAc, ethyl acetate; HATU, \\ 1-[bis(dimethylamino)methylene]-1H-1,2,3-triazolo[4,5-b]pyridinium \\ 3-oxide \\ hexafluorophosphate; LCMS, liquid chromatography mass spectrometry; LHMDS, lithium \\ bis(trimethylsilyl)amide; HRMS, high resolution mass spectrometry; $\mathrm{MeCN}$, acetonitrile; \\ TFA, trifluoroacetic acid; THF, tetrahydrofuran.
}

\title{
References
}

1. WHO Coronavirus (COVID-19) Dashboard. https://covid19.who.int (accessed Jan 20, 2022).

2. WHO Target Product Profiles for COVID-19 Therapeutics for non-hospitalized patients. https://www.who.int/publications/m/item/who-target-product-profiles-for-covid-19therapeutics-for-non-hospitalized-patients (accessed Jan 12, 2022)

3. Hu, B.; Guo, H.: Zhou, P.; Shi, Z. -L. Characteristics of SARS-CoV-2 and COVID-19. Nat. Rev. Microbiol. 2021, 19, 141-154. 
4. Ullrich, S.; Nitsche, C. The SARS-CoV-2 main protease as drug target. Bioorg. Med. Chem. Lett. 2020, 30, 127377.

5. Agbowuro, A. A.; Huston, W. M.; Gamble, A. B.; Tyndall, J. D. A. Proteases and protease inhibitors in infectious diseases. Med. Res. Rev. 2018, 38, 1295-1331.

6. Qiao, J.; Li, Y.-S.; Zeng, R.; Liu, F.-L.; Luo, R.-H.; Huang, C.; Wang, Y.-F.; Zhang, J.; Quan, B.; Shen, C.; Mao, X.; Liu, X.; Sun, W.; Yang, W.; Ni, X.; Wang, K.; Xu, L.; Duan, Z.-L.; Zou, Q.-C.; Zhang, H.-L.; Qu, W.; Long, Y.-H.-P.; Li, M.-H.; Yang, R.C.; Liu, X.; You, J.; Zhou, Y.; Yao, R.; Li, W.-P.; Liu, J.-M.; Chen, P.; Liu, Y.; Lin, G.F.; Yang, X.; Zou, J.; Li, L.; Hu, Y.; Lu, G.-W.; Li, W.-M.; Wei, Y.-Q.; Zheng, Y.-T.; Lei, J. SARS-CoV-2 $\mathrm{M}^{\text {pro }}$ inhibitors with antiviral activity in a transgenic mouse model. Science 2021, 371, 1374-1378.

7. Dampalla, C. S.; Zheng, J.; Perera, K. D.; Wong, L. Y. R.; Meyerholz, D. K.; Nguyen, H. N.; Kashipathy, M. M.; Battaile, K. P.; Lovell, S.; Kim, Y.; Perlman, S.; Groutas, W. C.; Chang, K. -O. Postinfection treatment with a protease inhibitor increases survival of mice with a fatal SARS-CoV-2 infection. Proc. Natl. Acad. Sci. U.S.A. 2021, 118, e2101555118.

8. Owen, D. R.; Allerton, C. M. N.; Anderson, A. S.; Aschenbrenner, L.; Avery, M.; Berritt, S.; Boras, B.; Cardin, R. D.; Carlo, A.; Coffman, K. J.; Dantonio, A.; Di, L.; Eng, H.; Ferre, R.; Gajiwala, K. S.; Gibson, S. A; Greasley, S. E.; Hurst, B. L.; Kadar, E. P.; Kalgutkar, A. S.; Lee, J. C.; Lee, J.; Liu, W.; Mason, S. W.; Noell, S.; Novak, J. J.; Obach, R S.; Ogilvie, K.; Patel, N. C.; Pettersson, M.; Rai, D. K.; Reese, M. R.; Sammons, M. F.; Sathish, J. G.; Singh, R. P.; Steppan, C. M.; Stewart, A. E.; Tuttle, J. B.; Updyke, L.; Verhoest, P. R.; Wei, L.; Yang, Q.; Zhu, Y. An oral SARS-CoV-2 $\mathrm{M}^{\text {pro }}$ inhibitor clinical candidate for the 
treatment of COVID-19. Science 2021, 374, 1586-1593.

9. Pelly, S.; Liotta, D. Potent SARS-CoV-2 Direct-acting antivirals provide an important complement to COVID-19 vaccines. ACS Cent. Sci. 2021, 7, 396-399.

10. Zhang, L.; Lin, D.; Sun, X.; Curth, U.; Drosten, C.; Sauerhering, L.; Becker, S.; Rox, K.; Hilgenfeld, R. Crystal structure of SARS-CoV-2 main protease provides a basis for design of improved $\alpha$-ketoamide inhibitors. Science (Washington, DC, U. S.) 2020, 368, $409-412$.

11. Mengist, H. M.; Mekonnen, D.; Mohammed, A.; Shi, R; Jin, T. Potency, safety, and pharmacokinetic profiles of potential inhibitors targeting SARS-CoV-2 main protease. Front. Pharmacol. 2020, 11, 630500.

12. Jacobs, J.; Grum-Tokars, V.; Zhou, Y.; Turlington, M.; Saldanha, S. A.; Chase, P.; Eggler, A.; Dawson, E. S.; Baez-Santos, Y. M.; Tomar, S.; Mielech, A. M.; Baker, S. C.; Lindsley, C. W.; Hodder, P.; Mesecar, A.; Stauffer, S. R. Discovery, synthesis, and structure-based optimization of a series of $N$-(tert-butyl)-2-(N-arylamido)-2-(pyridin-3-yl) acetamides (ML188) as potent noncovalent small molecule inhibitors of the severe acute respiratory syndrome coronavirus (SARS-CoV) 3CL protease. J. Med. Chem. 2013, 56, 534-546.

13. Turlington, M.; Chun, A.; Tomar, S.; Eggler, A.; Grum-Tokars, V.; Jacobs, J.; Daniels, J. S.; Dawson, E.; Saldanha, A.; Chase, P.; Baez-Santos, Y. M.; Lindsley, C. W.; Hodder, P.; Mesecar, A. D.; Stauffer, S. R. Discovery of $N$-(benzo[1,2,3]triazol-1-yl)- $N$ (benzyl)acetamido)phenyl) carboxamides as severe acute respiratory syndrome coronavirus (SARS-CoV) 3CLpro inhibitors: identification of ML300 and noncovalentnanomolar inhibitors with an induced-fit binding. Bioorg. Med. Chem. Lett. 
2013, 23, 6172-6177.

14. Han, S. H.; Goins, C. M.; Arya, T.; Shin, W. J.; Maw, J.; Hooper, A.; Sonawane, D. P.; Porter, M. R.; Bannister, B. E.; Crouch, R. D.; Lindsey, A. A.; Lakatos, G.; Martinez, S. R.; Alvarado, J.; Akers, W. S.; Wang, N. S.; Jung, J. U.; Macdonald, J. D.; Stauffer, S. R. Structure-based optimization of ML300-derived, noncovalent inhibitors targeting the severe acute respiratory syndrome coronavirus $3 \mathrm{CL}$ protease (SARS-CoV-2 $3 \mathrm{CL}^{\text {pro }}$ ). $J$. Med. Chem. 2021, DOI: 10.1021/acs.jmedchem.1c00598.

15. Douangamath, A.; Fearon, D.; Gehrtz, P.; Krojer, T.; Lukacik, P.; Owen, C. D.; Resnick, E.; Strain-Damerell， C.; Aimon，A.; Ábrányi-Balogh， P.; Brandão-Neto, J.; Carbery, A.; Davison, G.; Dias, A.; Downes, T. D.; Dunnett, L.; Fairhead, M.; Firth, J. D.; Jones, S. P.; Keeley, A.; Keserü, G. M.; Klein, H. F.; Martin, M. P.; Noble, M. E. M.; O’Brien, P.; Powell, A.; Reddi, R. N.; Skyner, R.; Snee, M.; Waring, M. J.; Wild, C.; London, N.; von Delft, F.; Walsh, M. A. Crystallographic and electrophilic fragment screening of the SARS-CoV-2 main protease. Nat. Commun. 2020, 11, 5047.

16. The COVID Moonshot Consortium; Achdout, H.; Aimon, A.; Bar-David, E.; Barr, H.; Ben-Shmuel, A.; Bennett, J.; Bobby, M. L.; Borden, B.; Bowman, G. R.; Brun, J.: BVNBS S.; Calmiano, M.; Carbery, A.; Cattermole, E.; Chernyshenko, E.; Chodera, J. D.; Clyde, A.; Coffland, J. E.; Cohen, G.; Cole, J.; Contini, A.; Cox, L.; Cvitkovic, M.; Dias, A.; Donckers, K.; Dosten, D. L.; Douangamath, A.; Duberstein, S.; Dudgeon, T.; Dunnett, L.; Eastman, P. K.; Erez, N.; Eyermann, C. J.; Fairhead, M.; Fate, G.; Fearon, D.; Fedorov, O.; Ferla, M.; Fernandes, R. S.; Ferrins, L.; Foster, R.; Foster, H.; Gabizon, R.; Garcia-Sastre, A.; Gawriljuk, V. O.; Gehrtz, P.; Gileadi, C.; Giroud, C.; Glass, W. 
G.; Glen, R.; Glinert, I.; Godoy, A. S.; Gorichko, M.; Gorrie-Stone, T.; Griffen, E. J.; Hart, S. H.; Heer, J.; Henry, M.; Hill, M.; Horrell, S.; Hurley, M. F. D.; Israely, T.; Jajack, A.; Jnoff, E.; Jochmans, D.; John, T.; Jonghe, S. D.; Kantsadi, A. L.; Kenny, P. W.; Kiappes, J. L.; Koekemoer, L.; Kovar, B.; Krojer, T.; Lee, A. A.; Lefker, B. A.; Levy, H.; London, N.; Lukacik, P.; Macdonald, H. B.; MacLean, B.; Malla, T. R.; Matviiuk, T.; McCorkindale, W.; MacGovern, B. L.; Melamed, S.; Michurin, O.; Mikolajek, H.; Milne, B. F.; Morris, A.; Morris, G. M.; Morwitzer, M. J.; Moustakas, D.; Nakamura, A. M.; Neto, J. B.; Neyts, J.; Nguyen, L.; Noske, G. D.; Oleinikovas, V.; Olivia, G.; Overheul, G. J.; Owen, D.; Psenak, V.; Pai, R.; Pan, J.; Paran, N.; Perry, B.; Pingle, M.; Pinjari, J.; Politi, B.; Powell, A.; Puni, R.; Rangel, V. L.; Reddi, R. N.; Reid, S. P.; Resnick, Ripika, E. G.; Robinson, M. C.; Robinson, R. P.; Rodriguez-Guerra, J.; Rosales, R.; Rufa, D.; Schofield, C.; Shafeev, M.; Shaikh, A.; Shi, J.; Shurrush, K.; Singh, S.; Sittner, A.; Skyner, R.; Smalley, A.; Smilova, M. D.; Solmesky, J.; Spencer, J.; StrainDamerell, C.; Swamy, V.; Tamir, H.; Tennant, R.; Thompson, A.; Thompson, W.; Tomasio, S.; Tumber, A.; Vakonakis, I.; van Rij, R. P.; Vangeel, L.; Varghese, F. S.; Vaschetto, M.; Vitner, E. B.; Voelz, V.; Volkamer, A.; von Delft, A.; von Delft, F.; Walsh, M.; Ward, W.; Weatherall, C.; Weiss, S.; White, K. M.; Wild, C. F.; Wittmann, M.; Wright, N.; Yahalom-Ronen, Y.; Zaidmann, D.; Zidane, H.; Zitzmann, N. Open science discovery of oral non-covalent SARS-CoV-2 main protease inhibitor therapeutics. bioRxiv 2020, DOI: $10.1101 / 2020.10 .29 .339317 \mathrm{v} 2$.

17. Peach, M. L.; Nicklaus, M. C. Combining docking with pharmacophore filtering for improved virtual screening. J. Cheminformatics 2009, 1, 6 . 
18. Yang, H; Xie, W; Xue, X; Yang, K; Ma, J; Liang, W; Zhao, Q; Zhou, Z; Pei, D; Ziebuhr, J; Hilgenfeld, R; Yuen, K. Y.; Wong, L; Gao, G.; Chen, S.; Chen, Z.; Ma, D.; Bartlam, M.; Rao, Z. Design of wide-spectrum inhibitors targeting coronavirus main proteases. PLoS Biol. 2005, 3, e324.

19. Mesecar, A. D. Structure of COVID-19 main protease bound to potent broad-spectrum non-covalent inhibitor X77. 2020, PDB ID 6W63.

20. Wang, R.; Zhang, Q.; Ge, J.; Ren, W.; Zhang, R.; Lan, J.; Ju, B.; Su, B.; Yu, F.; Chen, P.; Liao, H.; Feng, Y.; Li, X.; Shi, X.; Zhang, Z.; Zhang, F.; Ding, Q.; Zhang, T.; Wang, X.; Zhang, L. Analysis of SARS-CoV-2 variant mutations reveals neutralization escape mechanisms and the ability to use ACE2 receptors from additional species. Immunity 2021, 54, 1611-1621.e5.

21. Kai, H.; Kameyama, T.; Horiguchi, T.; Asahi, K.; Endoh, T.; Fujii, Y.; Shintani, T.; Nakamura, K.; Matsumoto, S.; Hasegawa, T.; Oohara, M.; Tada, Y.; Maki, T.; Iida, A. Preparation of triazine derivatives and pharmaceutical compound that contains same and exhibits analgesic activity. WO 2012020749 A1, Feb 16, 2012.

22. Al-Awar, R.; Isaac, M.; Chau, A. M.; Mamai, A.; Watson, I.; Poda, G.; Subramanian, P.; Wilson, B.; Uehling, D.; Prakesch, M.; Joseph, B.; Morin, J. A. Preparation of substituted pyrrolopyrimidinylacetamides as inhibitors of the BCL6 BTB domain protein-protein interaction and uses thereof. WO 2019153080 A1, Aug 15, 2019.

23. Sasaki, M.; Uemura, K.; Sato, A.; Toba, S.; Sanaki, T.; Maenaka, K.; Hall, W. W.; Orba, Y.; Sawa, H. SARS-CoV-2 variants with mutations at the S1/S2 cleavage site are 
generated in vitro during propagation in TMPRSS2-deficient cells. PLoS Pathog. 2021, $17, \mathrm{e} 1009233$.

24. Thai, H. T. C.; Le, M. Q.; Vuong, C. D.; Parida, M.; Minekawa, H.; Notomi, T.; Hasebe, F.; Morita, K. Development and evaluation of a novel loop-mediated isothermal amplification method for rapid detection of severe acute respiratory syndrome coronavirus. J. Clin. Microbiol. 2004, 42, 1956-1961.

25. Raj, V. S.; Mou, H.; Smits, S. L.; Dekkers, D. H. W.; Müller, M. A.; Dijkman, R.; Muth, D.; Demmers, J. A. A.; Zaki, A.; Fouchier, R. A. M.; Thiel, V.; Drosten, C.; Rottier, P. J. M.; Osterhaus, A. D. M. E.; Bosch, B. J.; Haagmans, B. L. Dipeptidyl peptidase 4 is a functional receptor for the emerging human coronavirus-EMC. Nature 2013, 495, 251-254.

26. Pauwels, R.; Balzarini, J.; Baba, M.; Snoeck, R.; Schols, D.; Herdewijn, P.; Desmyter, J.; De Clercq, E. Rapid and automated tetrazolium-based colorimetric assay for the detection of anti-HIV compounds. J. Virol. Methods 1988, 20, 309-321.

27. Vijgens, L.; Keyaerts, E.; Moes, E.; Maes, P.; Duson, G.; Van Ranst, M. Development of one-step, real-time, quantitative reverse transcriptase PCR assays for absolute quantitation of human coronaviruses OC43 and 229E. J. Clin. Microbiol. 2005, 43, $5452-5456$.

28. Sastry, G. M.; Adzhigirey, M.; Day, T.; Annabhimoju, R.; Sherman, W. Protein and ligand preparation: parameters, protocols, and influence on virtual screening enrichments. J. Comput. Aided Mol. Des. 2013, 27, 221-234. 
29. Greenwood, J. R.; Calkins, D.; Sullivan, A. P.; Shelley, J. C. Towards the comprehensive, rapid, and accurate prediction of the favorable tautomeric states of drug-like molecules in aqueous solution. J. Comput. Aided Mol. Des, 2010, 24, 591-604.

30. Shelley, J. C.; Cholleti, A.; Frye, L.; Greenwood, J. R.; Timlin, M. R.; Uchimaya, M. Epik: a software program for pKa prediction and protonation state generation for druglike molecules, J. Comput. Aided Mol. Des, 2007, 21, 681-691.

31. Schrödinger Release 2019-4: LigPrep, Schrödinger, LLC, New York, NY, 2021.

32. Halgren, T. A.; Murphy, R. B.; Friesner, R. A.; Beard, H. S.; Frye, L. L.; Pollard, W. T.; Banks, J. L. Glide: a new approach for rapid, accurate docking and scoring. 2. Enrichment factors in database screening. J. Med. Chem. 2004, 47, 1750-1759.

33. Friesner, R. A.; Banks, J. L.; Murphy, R. B.; Halgren, T. A.; Klicic, J. J.; Mainz, D. T.; Repasky, M. P.; Knoll, E. H.; Shelley, M.; Perry, J. K.; Shaw, D. E.; Francis, P.; Shenkin, P. S. Glide: a new approach for rapid, accurate docking and scoring. 1. Method and assessment of docking accuracy. J. Med. Chem. 2004, 47, 1739-1749.

34. Dixon, S. L.; Smondyrev, A. M.; Knoll, E. H.; Rao, S. N.; Shaw, D. E.; Friesner, R. A. PHASE: a new engine for pharmacophore perception, 3D QSAR model development, and 3D database screening. 1. Methodology and preliminary results. J. Comput. Aided Mol. Des. 2006, 20, 647-671.

35. Dixon, S. L.; Smondyrev, A. M.; Rao, S. N. PHASE: a novel approach to pharmacophore modeling and 3D database searching, Chem. Biol. Drug Des. 2006, 67, 370-372. 
36. Matsumoto, T.; Yamano, A.; Sato, T.; Ferrara, J. D.; White, F. J.; Meyer, M. "What is this?" A structure analysis tool for rapid and automated solution of small molecule structures. J. Chem. Crystallogr. 2021, 51, 438-450.

37. Vagin, A.; Teplyakov, A. MOLREP: an automated program for molecular replacement. J. Appl. Crystallogr. 1997, 30, 1022-1025.

38. Jin, Z.; Du, X.; Xu, Y.; Deng, Y.; Liu, M.; Zhao, Y.; Zhang, B.; Li, X.; Zhang, L.; Peng, C.; Duan, Y.; Yu, J.; Wang, L.; Yang, K.; Liu, F.; Jiang, R.; Yang, X.; You, T.; Liu, X.; Yang, X.; Bai, F.; Liu, H.; Liu, X.; Guddat, L. W.; Xu, W.; Xiao, G.; Qin, C.; Shi, Z.; Jiang, H.; Rao, Z.; Yang, H. Structure of $\mathrm{M}^{\text {pro }}$ from SARS-CoV-2 and discovery of its inhibitors. Nature 2020, 582, 289-293.

39. Emsley, P.; Lohkamp, B.; Scott, W. G.; Cowtan, K. Features and development of Coot. Acta Crystallogr. 2010, D66, 486-501.

40. Murshudov, G. N.; Vagin, A. A.; Dodson, E. J. Refinement of macromolecular structures by the maximum-likelihood method. Acta Crystallogr. 1997, D53, 240-255. 